\title{
Revision of the genera Nemadiopsis and Falkonemadus (Coleoptera: Leiodidae: Cholevinae)
}

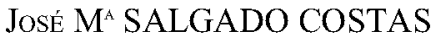 \\ Animal Biology Department, León University, 24071 León, Spain; e-mail: dbajsc@unileon.es
}

Key words. Coleoptera, Leiodidae, Cholevinae, Nemadiopsis, Falkonemadus, taxonomy, revision, new species, synonymy

\begin{abstract}
The genera Nemadiopsis Jeannel, 1936 and Falkonemadus Szymczakowski, 1961 are redescribed and revised. The taxonomic position of Nemadiopsis and Falkonemadus is analy sed using features of male and female genitalia. Two new subgenera, Nemadiopsicus subgen. n. and Nemadiopsella subgen. n. and five new species, Nemadiopsis (Nemadiopsis) grossicornis sp. n., $N$. (Nemadiopsicus) rotundatus sp. n., N. (Nemadiopsella) curvipes $\mathrm{sp}$. n., Falkonemadus similaris $\mathrm{sp} . \mathrm{n}$. and F. avicularis $\mathrm{sp} . \mathrm{n}$. are described. Keys to the subgenera and species are given. Nemadiopsis (Nemadiopsis) edwardsi Jeannel, 1936 and $N$. (N.) irretusus Szymczakowski, 1962 are proposed as junior subjective synonyms of Nemadiopsis (N.) fastidiosus (Fairmaire et Germain, 1859).
\end{abstract}

\section{INTRODUCTION}

According to Newton (1998), the family Leiodidae consists of 5 subfamilies, one of which is the subfamily Cholevinae. All taxa in this subfamily exhibit the following: occipital carina or crest (when present) resting against front of pronotum when the head is in repose; cervical sclerites present; procoxal cavities internally closed behind. Newton (1998) proposed 6 tribes within the subfamily Cholevinae, one being the tribe Anemadini Hatch, 1928. This tribe consists of 4 subtribes, including the subtribe Eunemadina Newton, 1998, characterised by the absence of an epistomal suture and the basal lobes of the parameres of the aedeagus meeting ventrally. This subtribe includes 19 genera distributed throughout the Nearctic, and particularly the Australian and Neotropical regions. Amongst these genera are Nemadiopsis Jeannel, 1936, found in Chile and Argentina, and Falkonemadus Szymczakowski, 1961, in Chile and the Falkland Islands. Both genera, as indicated in the description, are easily distinguished as Nemadiopsis exhibits the following: apical segment of maxillary palp usually not much shorter than, and at least $2 / 3$ as wide at base as penultimate segment; occipital crest strongly elevated throughout; parameres of aedeagus each with two long setae (Figs 3, 18 and 37). Whilst the apical segment of the maxillary palp in Falkonemadus is very small, much shorter than and only half as wide at base as penultimate segment (Fig. 40); occipital crest scarcely elevated above neck at midline; parameres of aedeagus glabrous or with a very small seta (Figs 45, 53 and 58).

The genus Nemadiopsis was established by Jeannel (1936), and included two species, N. fastidiosus (Fairmaire et Germain, 1859), from Chile, and N. edwardsi Jeannel, 1936, from Argentina.

New descriptions of species were published subsequently by two authors (Jeannel, 1957, 1962; Szymczakowski, 1961, 1962, 1965, 1968, 1971, 1976) who provided new data on the geographical distribution of some of the species. Until 1976 the number of species belonging to the genus Nemadiopsis was 8 . In this taxonomic revision in spite of the description of 3 new species, the number of species included in the genus is 7 ; 3 belong to the subgenus Nemadiopsis s. str., 3 to Nemadiopsicus subgen. $\mathrm{n}$. and 1 to Nemadiopsella subgen $\mathbf{n}$. This is because the synonymies of Nemadiopsis edwardsi Jeannel, 1936 and Nemadiopsis irretusus Szymczakowski, 1962, and the formation of new taxonomic groups. For this reason Nemadiopsis carbonarius Szymczakowski, 1961, is not mentioned in this paper as it belongs in another genus and neither is Nemadiopsis malleatus Szymczakowski, 1976, which is the type species of a new genus; these changes will be published separately. All the species of the genus Nemadiopsis are known only from Chile and Argentina.

Salgado (1991) provides data on three species of the genus Nemadiopsis, and Newton (1998) and Perreau (2000) include all the species in their respective catalogues.

The genus Falkonemadus was established by Szymczakowski (1961) for F. sphenisci Szymczakowski, 1961. The specimens were found in the corpse and stomach of the penguin, Spheniscus magellanicus Forster, 1781, on the Falkland Islands. No data was published on this genus since 1961. Therefore the two species described in this paper and the data on $F$. sphenisci are new.

\section{MATERIAL AND METHODS}

This is the second part of a study on the Anemadini from South America, and completes that of Salgado (2000). Material belonging to the FMNH (Field Museum of Natural History, Chicago, Illinois, U.S.A.) was examined, as in the previous paper. Of the 2330 specimens examined, 2271 (1613 males - 658 females) belong to the genus Nemadiopsis and 59 (31 males 28 females) to the genus Falkonemadus. They were nearly all collected by S. \& J. Peck (1976 and 1984-85) and A. Newton and M. Thayer (1982-83 and 1996-97) on various expeditions. Small contributions were also made by T. Cekalovic, L. Masner and L. Peña. Selected specimens, including paratypes of new 


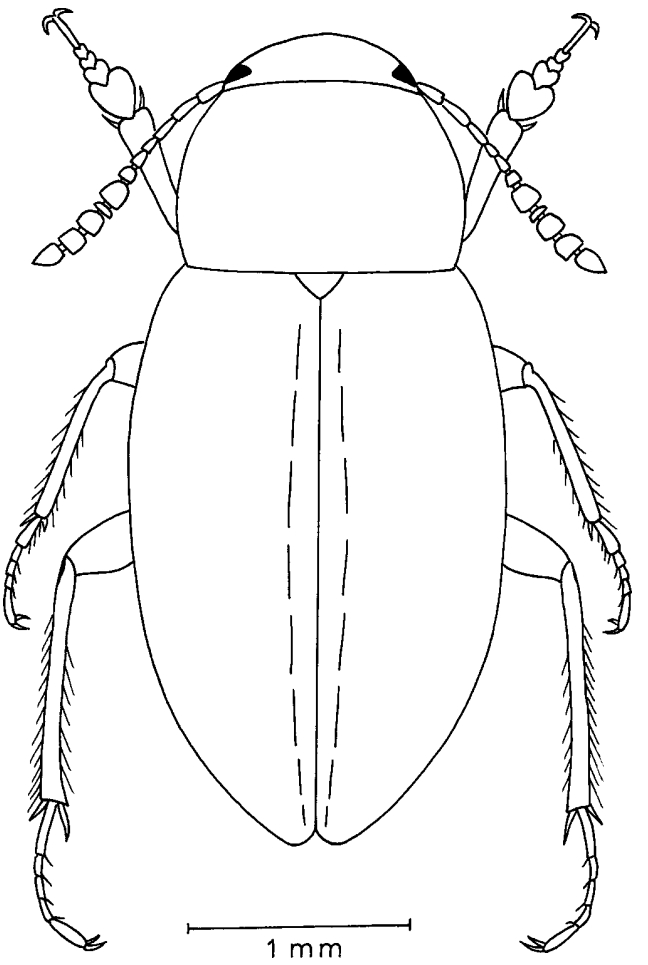

Fig.1. Habitus of Nemadiopsis (Nemadiopsicus) rotundatus sp. n.

species, will be deposited in the MNNC (Museo Nacional de Historia Natural, Santiago, Chile) and the Salgado Collection.

Nemadiopsis and Falkonemadus specimens were collected in different types of animal or vegetable material, in this case in humus and fallen leaves in Nothofagus (N. dombeyi, N. pumilio, $N$. obliqua, $N$. betuloides and $N$. alpina), Araucaria araucana and Pinus sp. forests, and beneath Chusquea, Saxegothaea, Podocarpus and Drimys. All collections were made at altitudes of between 25 and 1650 metres. Pitfall traps baited with excrement or carrion (Newton \& Peck, 1975), window (= flight intercept) traps, Berlese sampling of forest floor leaf litter, and light traps were used.

Prior to the dissection of the genitalia of dried specimens mounted on cards fixed on entomological pins they were first relaxed in boiling water and then softened in $10 \% \mathrm{KOH}$ for 24 hours. The dissected specimens were then mounted as previously described and the genitalia mounted in "Hoyer liquid" on microslides, attached to the same pin

\section{SYSTEMATIC STUDY}

\section{Tribe Anemadini Hatch, 1928; Subtribe Eunemadina} Newton, 1998

\section{Genus Nemadiopsis Jeannel, 1936}

Nemadiopsis Jeannel, 1936: 159.

Type species. Choleva fastidiosa Fairmaire et Germain, 1859 by original designation

Nemadiopsis: Jeannel, 1957: 54.

Nemadiopsis: Jeannel, 1962: 520.

Nemadiopsis: Szymczakowski, 1962: 123.

Nemadiopsis: Newton, 1998: 104.

Nemadiopsis: Perreau, 2000: 62.
Diagnosis. Body length between $2.90 \mathrm{~mm}$ and $4.50 \mathrm{~mm}$ (Fig. 1). Punctures on head clearly visible. Eyes fully developed. Pronotum clearly transverse, narrower than elytra. Elytra convex, apex rounded and with well defined sutural stria and transverse striae. Wings well developed. Pubescence short, yellow and prostrate. Mesosternum with fine carina, generally discernible in anterior region and more visible in posterior region; male metasternum not tuberculate. Legs robust, outer spurs of mesotibiae and metatibiae shorter than first tarsomere. First four segments of protarsi dilated in males, first one always greatly so. First segment of mesotarsi more or less dilated, wider than second, more or less expanded outwards. Genital segment complete with sternal apophysis well-developed, wide or narrow (Figs 13, 23, 28 and 36).

Trilobed aedeagus with or without setae on lateral margins of median lobe (Figs 3, 8, 18 and 24), internal sac with different structures depending on the species (Figs 9, 14, 29 and 37); parameres with two closely inserted apical setae with or without setae on interior margins (Figs 14, 29 and 37). The morphology of female genitalia, which has not been previously examined, is not uniform. In many cases, this will allow the species to be differentiated from others. The spiculum ventrale, an anterior projection of abdominal sternite VIII is very different in some of the species (Figs 5, 10, 15, 31 and 38), as well as the spermatheca, which can be classified as follows (Perreau, 1989), "type 1" with differentiated and well sclerotized lobes (Figs 6, 11 and 16) and "type 3" with the spermatheca in the form of an almost completely membranous elongated globose sac (Figs 21, 26 and 32).

\section{KEY TO THE SUBGENERA AND SPECIES OF THE GENUS NEMADIOPSIS}

1. Apex of metatrochanters strongly pointed, generally curved in the male (Fig. 35). Antennal club segments very separated, $8^{\text {th }}, 9^{\text {th }}$ and $10^{\text {th }}$ segments transverse (Fig. 33). Parameres of aedeagus with small setae on internal margin (Fig. 37). Apical region of spiculum ventrale expanded (Fig. 38)

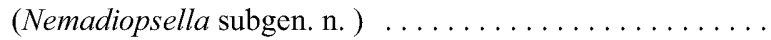
N. (Nemadiopsella) curvipes sp. $\mathrm{n}$.

- Apex of the metatrochanters weakly pointed, never curved. Antennal club segments weakly or not separated, segments transverse, but different from the previous ones. Parameres of aedeagus lacking setae on internal margin. Apex of spiculum ventrale with parallel sides and a rounded apex ...

$$
\text { ............................. } 2
$$

2. Genital segment as long as or slightly longer than wide (Figs 23,28 ). Lateral margins of median lobe of aedeagus bearing setae (Figs 18, 29). Basal lamina of aedeagus longer than median lobe (Figs 18, 21). Sternite of VII female abdominal segment with a lobe on median posterior margin (Figs 19, 30). Spermatheca membranous, and shaped like an elongated sac (Figs 26, 32) (Nemadiopsicus subgen. n.) .....

$$
\ldots \ldots \ldots \ldots \ldots \ldots \ldots \ldots \ldots \ldots \ldots \ldots \ldots \ldots \ldots \ldots \ldots \ldots \ldots
$$

Genital segment wider than long (Fig. 13). Lateral margins of median lobe of aedeagus lacking setae (Figs 3, 14). Basal lamina of aedeagus shorter than median lobe (Figs 3, 8). Sternite of VII abdominal segment widely arched in the female, and lacking a lobe (Fig. 4). Spermatheca formed by two clearly visible sclerotized lobes (Figs 6, 16) (Nemadiopsis s. str.) .................... 5 
3. $5^{\text {th }}, 6^{\text {th }}, 8^{\text {th }}, 9^{\text {th }}$ and $10^{\text {th }}$ antennal segments transverse (Fig. 27). Median lobe of aedeagus wide medially with noticeable small marginal setae (Fig. 29). Internal sac of aedeagus with groups of long sclerotized fibres in the form of an arch (Fig. 29) ................ (Nemadiopsicus) rotundatus sp. n. $6^{\text {th }}$ and $8^{\text {th }}$ antennal segments transverse (Figs 17, 22). Median lobe of aedeagus narrower at middle, marginal setae longer (Figs 18, 24). Internal sac of aedeagus lacking fibres in the form of an arch ................... 4

4. Apex of median lobe of aedeagus narrowing into short blunt tip. Parameres slightly surpassing apex of median lobe of aedeagus (Fig. 18). Sagitta of spiculum ventrale not easily discernible (Fig. 20) ..... N. (Nemadiopsicus) barbarae

- Apex of median lobe of aedeagus narrowing into long pointed tip. Parameres clearly surpassing tip of median lobe of aedeagus (Fig. 24). Sagitta of spiculum ventrale easily discernible (Fig. 25) . ....N. (Nemadiopsicus) trichophorus

5. $7^{\text {th }}$ antennal segment longest and most robust; $4^{\text {th }}$ and $5^{\text {th }}$ segments transverse (Fig. 12). Apex of median lobe of aedeagus wide. Parameres not exceeding apex of median lobe of aedeagus, microdentate on internal margin (Fig. 14). Small spermathecal lobes (Fig. 16)

.................. (Nemadiopsis) grossicornis sp. $\mathrm{n}$. $7^{\text {th }}, 9^{\text {th }}$ and $10^{\text {th }}$ antennal segments similar in length and width; $4^{\text {th }}$ and $5^{\text {th }}$ segments not transverse (Figs 2, 7). Apex of median lobe of aedeagus narrow. Parameres clearly surpassing apex of median lobe of aedeagus, lacking microdentation (Figs 3, 8). Larger spermathecal lobes (Figs 6, 11) . .

....................................... 6

6. Several small, shallow punctures on head. Male protars wider than tibia. Apex of median lobe of aedeagus pointed. Parameres only just surpassing apex of median lobe, setae very closely inserted (Fig. 8). Sagitta of spiculum ventrale weakly or not distinguishable(Fig. 10) ..............

$\ldots \ldots \ldots \ldots \ldots \ldots \ldots \ldots$. N (Nemadiopsis) fastidiosus rower or as wide as tibia. Apex of median lobe of aedeagus not pointed. Parameres clearly surpassing median lobe, insertion pores separated (Fig. 3). Sagitta of spiculum ventrale well-defined (Fig. 5) ... N. (Nemadiopsis) rufimanus

\section{Subgenus Nemadiopsis s. str.}

Diagnosis. Certain characteristics of this subgenus are of considerable taxonomic importance: the transverse $6^{\text {th }}$, $8^{\text {th }}$ and $10^{\text {th }}$ antennal segments (Figs 2, 7 and 12); lateral margins of median lobe lack setae, basal lamina of aedeagus shorter than median lobe (Figs 3, 8 and 14); posterior margin of sternite of VII abdominal segment in the female lacks a discernible lobe; and spermatheca with two sclerotized lobes joined by a membrane or hyaline area (Figs 6, 11 and 16).

The two main characters defining this subgenus: the lateral margin of the median lobe lacks setae and the spermatheca has two clearly sclerotized lobes.

\section{Nemadiopsis (Nemadiopsis) rufimanus Jeannel, 1962}

(Figs 2-6)

Nemadiopsis rufimanus Jeannel, 1962: 522.

Type locality. Chepu, Province of Chiloé (Chile). Type. Coll. Santiago Museum (Chile).

Nemadiopsis rufimanus: Szymczakowski, 1976: 433.

Nemadiopsis rufimanus: Salgado, 1991: 176.

Nemadiopsis rufimanus: Perreau, 2000: 63.

Redescription of male. Length: $2.90-3.40 \mathrm{~mm}$. Colour dark brown. Numerous large, deep, confluent points on head.

Antennae 1.6 times as long as pronotum (Fig. 2); $6^{\text {th }}$ to $10^{\text {th }}$ segments clearly transverse; $7^{\text {th }}, 9^{\text {th }}$ and $10^{\text {th }}$ almost the same size, slightly wider than $11^{\text {th }}$; using the length of the $9^{\text {th }}$ segment as a basis, relative length of each segment from $1^{\text {st }}$ to $11^{\text {th: }}: 1.63,1.37,1.48,0.95,0.84,0.58,1.03$, $0.42,1.00,1.00,1.63$; ratios of length to width for each segment: $2.82,2.37,2.15,1.37,1.00,0.63,0.77,0.50$, $0.73,0.75,1.50$.

Pronotum transverse, 1.65 times as wide as long; coarse, strong, dense, granulate punctures; sides weakly arched, widest at basal third, base wider than anterior region. Elytra together 1.46 times as long as wide and 3.13 times as long as the length of pronotum. Strioles
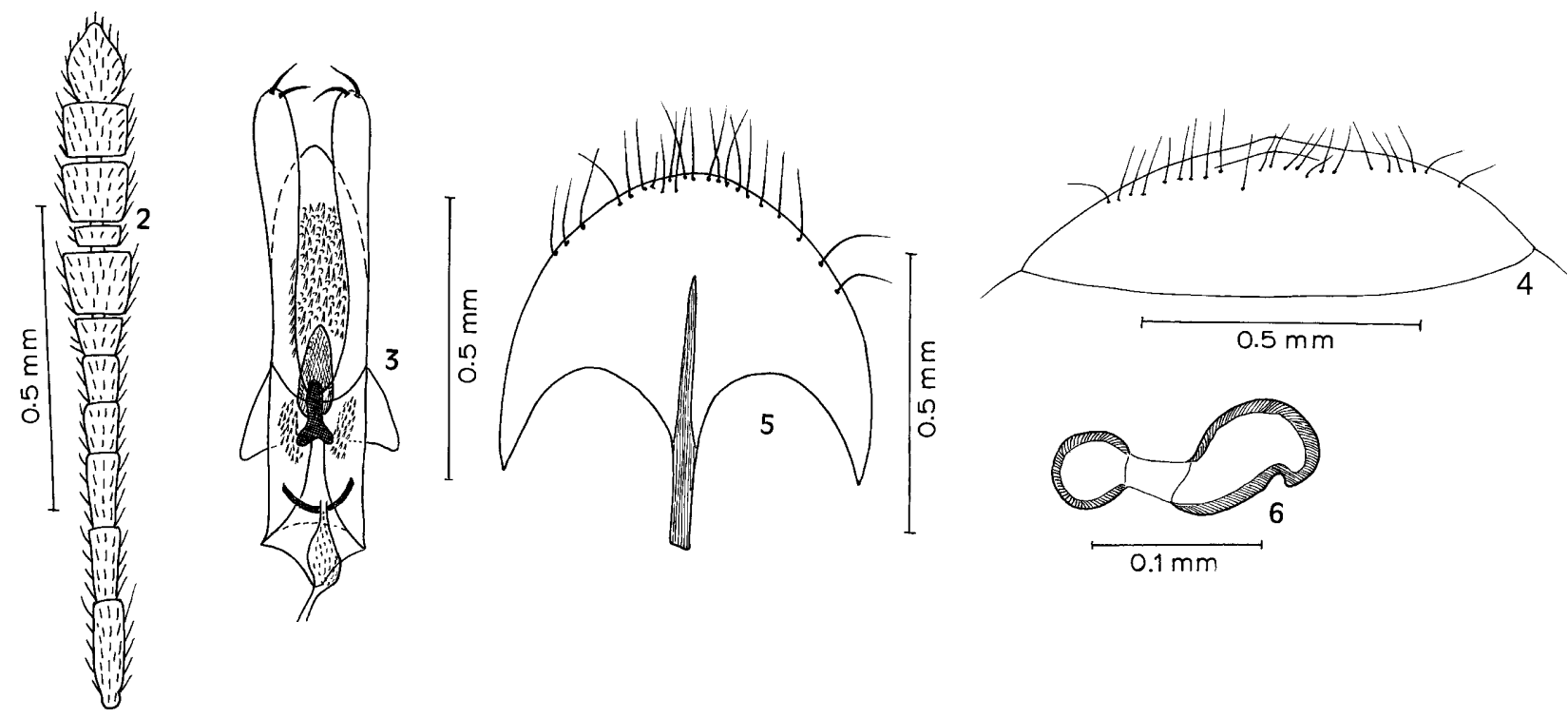

Figs 2-6. Nemadiopsis (Nemadiopsis) rufimanus. 2 - antenna; 3 - aedeagus, ventral view; 4 - VII abdominal segment; 5 spiculum ventrale, ventral view; 6 - spermatheca, lateral view. 
transverse and easily visible, fairly regular and perpendicular to suture. Median region of mesosternum with feebly-defined carina. Male protarsi expanded, first tarsomere 0.92 times wider than maximum width of tibia: first mesotarsus dilated and somewhat expanded outwards. Genital segment complete (see Salgado, 1991), slightly wider than long (1.08).

Aedeagus with elongate median lobe and blunt apex (Fig. 3). Basal lamina shorter than median lobe, with margin in mid apical region tapering into rounded lobe. Wide, robust parameres, clearly surpassing apex of median lobe; two setae with insertion pores separated. Internal sac with strongly sclerotized structures, in particular, a ventral piece on the median base in the shape of a robust tooth expanded at the base; the tooth is normally covered by an elongated oval-shaped lamina; latero-basal spines and fully-formed scaly areas alternating with spines along the median region.

Diagnosis of female. The female is generally more robust than the male, with shorter antennae and more transverse club segments: protarsi and first mesotarsal segment not dilated.

Posterior margin of sternite of VII abdominal segment a wide arch, slightly pointed in the middle (Fig. 4); VIII abdominal segment with spiculum ventrale fully formed towards front, towards back, in the median region of the sternite there is a sclerotized rod shape, which will be referred to as the "sagitta" (Fig. 5). "Type 1" spermatheca (Perreau, 1989) with two sclerotized lobes separated by a membranous region. Apical lobe round, basal lobe slightly oval in shape, wider and larger (Fig. 6).

Remarks. The pronounced punctuation on the head and pronotum, segments of the antennal club clearly transverse, and in particular, the aedeagus with a rounded median lobe at the apex, make this species very easily distinguishable, as well as the very long parameres, and very sclerotized structures of the internal sac, consisting of a large tooth and oval-shaped lamina.

\section{Material examined}

Chile. Cautín province: Parque Nacional Cerro Ñielol, Temuco, 14-30-XII-1982, 34m.-14f., A. Newton \& M. Thayer leg.; 13-XII-1984/12-II-1985, 22m.-8f., S. \& J. Peck leg.; Parque Nacional Conguillío, Laguna Captrén, 23-XII-1996/5-II1997, 4m., A. Newton \& M. Thayer leg.; Frutillar Bajo, 27-XII1984/2-II-1985, 1m., S. \& J. Peck leg.; Parque Nacional Villarrica, Volcán Villarrica, 15-29-XII-1982, 52m.-22f., A. Newton \& M. Thayer leg; 15-XII-1984/10-II-1985, 1m.-1f., S. \& J. Peck leg.; 23-XII-1996/5-II-1997, 2m., A. Newton \& M. Thayer leg.; Flor del Lago, 14-XII-1984/10-II-1985, 41m.-31f., S. \& J. Peck leg.; Bellavista, Lago Villarrica, 15-30-XII-1982, 31m.-14f., A. Newton \& M. Thayer leg. Chiloé province: I. Chiloé, Castro, 27-XII-1984/1-II-1985, 2f., S. \& J. Peck leg.; I. Chiloé, Ahoni Alto, 21-23-II-1988, 11m., L. Masner leg.; I. Chiloé, Melleico, 11-II-1994, 1f., T. Cekalovic leg. Concepción province: Estero Nonguén, 29-IV-1978, 3m.-2f., T. Cekalovic leg.; Las Escaleras, 29-VIII-1993, 1m., T. Cekalovic leg.; Puente Pelun, 21-II-1993, 1m.-2f., T. Cekalovic leg.; San Pedro, 12-XII-1982/2-I-1983, 31m.-16f., A. Newton \& M. Thayer leg. Llanquihue province: Lago Chapo, 16-27-XII-1982, 78m.-32f., A. Newton \& M. Thayer leg.; 24-XII-1984/2-II-1985, 24m.-7f., S. \& J. Peck leg.; 4-26-I-1997, 2m., A. Newton \& M. Thayer leg.; Frutillar Bajo, 22-XII-1984/2-II-1985, 1m., S. \& J. Peck leg.; Parque Nacional Vicente Pérez Rosales, Volcán Osorno, 3-27-I-1997, 2m.-1f., A. Newton \& M. Thayer leg.; P. N. Vicente Pérez Rosales, Ensenada, 2-28-I-1997, 3m., A. Newton \& M. Thayer leg.; P. N. Vicente Pérez Rosales, Salto Petrohué, 23-XII-1984/4-II-1985, 1m., S. \& J. Peck leg. Malleco province: Angol, 8-XII-1984/16-II-1985, 15m.-7f., S. \& J. Peck leg.; Parque Nacional Contulmo, Puren, 11-XII-1984/13-II-1985, 22m.-12f., S. \& J. Peck leg.; Curacautín, 12-XII-1984/16-II1985, 14m.-2f., S. \& J. Peck leg.; Princesa, 12-XII-1984/16-II1985, 1f., S. \& J. Peck leg.; Malalcahuello, 13-31-XII-1982, 75m.-39f., A. Newton \& M. Thayer leg.; 24-XII-1996/2-II-1997, 2f., A. Newton \& M. Thayer leg.; Manzanar, 19-25XII-1976, 35m.-28f., S. \& J. Peck leg.; Parque Nacional Nahuelbuta, Cabrería, 21-23-I-1977, 6f., L. Peña leg.; P. N. Nahuelbuta, Coimallín, 21-XII-1996/7-II-1997, 6m., A. Newton \& M. Thayer leg.; P. N. Nahuelbuta, Pichinahuel, 15-20-II-1977, 1m.-4f., L Peña leg.; Victoria, 26-31-XII-1976, 71m.-22f., S. \& J. Peck leg.; Villa Portales, 22-25-XII-1976, $17 \mathrm{~m} .-5 \mathrm{f} .$, S. \& J. Peck leg. Nuble province: Shangrila, 15-17XII-1976, 15m.-7f., S. \& J. Peck leg.; Las Trancas, 13-17-XII1976, 15m.-16f., S. \& J. Peck leg.; 10-XII-1982/3-II-1983, 67m.-29f., A. Newton \& M. Thayer leg.; 6-XII-1984/19-II-1985, 1m.-4f., S. \& J. Peck leg. Osorno province: Parque Nacional Puyehue, Aguas Calientes, 18-XII-1984/8-II-1985, 30m.-13f., S. \& J. Peck leg.; P. N. Puyehue, Antillanca road, 1825-XII-1982, 110m.-64f., A. Newton \& M. Thayer leg.; P. N. Puyehue, Antillanca road, 18-20-XII-1984, 2f., S. \& J. Peck; 29XII-1996/1-II-1997, 7m., A. Newton \& M. Thayer leg.; P. N. Puyehue, Anticura, 19-26-XII-1982, 1m., A. Newton \& M. Thayer leg.; 19-XII-1984/6-II-1985, 23m.-6f., S. \& J.Peck leg.; 12-II-1988, 1m.-1f., L. Masner leg.; P. N. Puyehue, Termas de Puyehue, 19-25-XII-1982, 23m.-19f., A. Newton \& M. Thayer leg.; P. N. Puyehue, Volcán Casa Blanca, 20-25-XII-1982, 2m., A. Newton \& M. Thayer leg.; Pucatrihue, 7-II-1979, 1m.-1f., Ashworth \& Gordon leg.; Bahía Mensa, 21-XII-1984/3-II-1985, 1f., S. \& J. Peck leg. Palena province: Chaitén, Ventisquero, 29-XII-1984/29-I-1985, 22m.-8f., S. \& J. Peck leg. Talca province: Alto Vilches, 10-13-XII-1976, 30m.-17f., S. \& J. Peck leg.; Area de Protección Vilches, 18-XII-1996-8-II-1997, A. Newton \& M. Thayer leg. Quillota Province: Parque Nacional La Campana, Olmue, 2-XII-1984, 1m.-1f., S. \& J. Peck leg. Valdivia province: Enco, 5-II-1978, 2f., L. Peña leg.; La Unión, 17-XII-1984/7-II-1985, 39m.-13f., S. \& J. Peck leg.; Panguipulli, 16-XII-1984/11-II-1985, 1f., S. \& J. Peck leg.; Parque Nacional Puyehue, Anticura, 19-25-XII-1982, 30m.-14f., A. Newton \& M. Thayer leg.; Puerto Fuy, 16-XII-1984/11-II1985, 1f., S. \& J. Peck leg.; Rincón de la Piedra, 11-I/2-II-1997, $4 \mathrm{~m}$., A. Newton \& M. Thayer leg.

\section{Nemadiopsis (Nemadiopsis) fastidiosus (Fairmaire \& Germain, 1859)}

(Figs 7-11)

Choleva fastidiosa Fairmaire \& Germain, 1859: 352.

Type locality. Quillota (Chile). Type. Coll. Museum d'Histoire Naturelle (Paris).

Eunemadus fastidiosus: Portevin, 1914: 193.

Nemadiopsis fastidiosus: Jeannel, 1936: 160.

Nemadiopsis edwardsi Jeannel, 1936: 160. syn. n.

Type locality. L. Nahuel Huapi, Río Negro (Argentina). Type. Coll. The Natural History Museum, London.

Nemadiopsis fastidiosus: Jeannel, 1957: 54.

Nemadiopsis edwardsi: Jeannel, 1962: 523. 

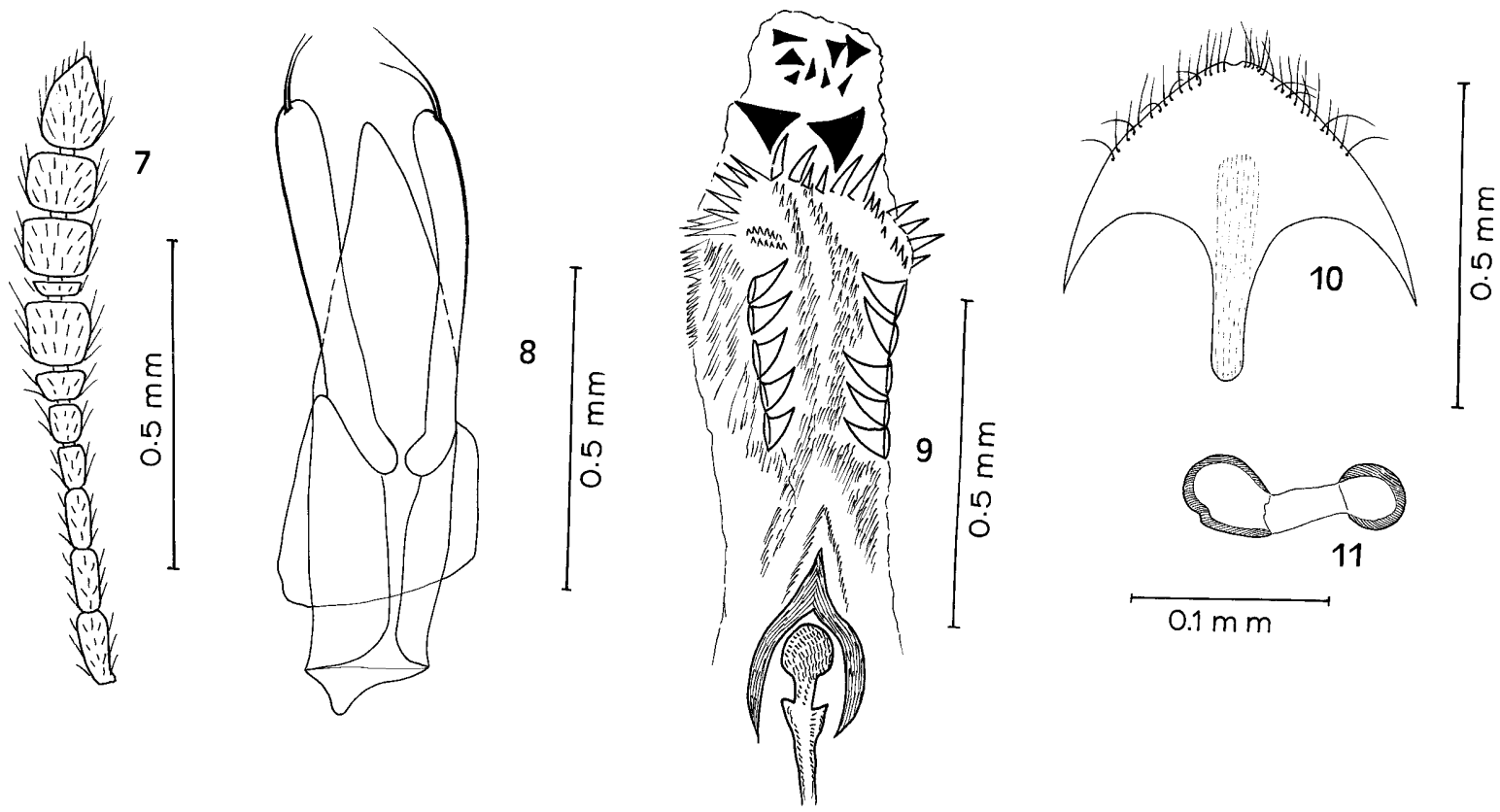

11

$0.1 \mathrm{~m} \mathrm{~m}$

Figs 7-11. Nemadiopsis (Nemadiopsis) fastidiosus. 7 - antenna; 8 - aedeagus without internal sac, dorsal view; 9 - internal sac, dorsal view; 10 - spiculum ventrale, ventral view; 11 - spermatheca, lateral view.

Nemadiopsis fastidiosus: Jeannel, 1962: 521.

Nemadiopsis brevicollis Jeannel, 1962: 522.

Type locality. Chepu (Chile). Type. Coll. Museum Santiago (Chile).

Nemadiopsis irretusus Szymczakowski, 1962: 23. syn. n.

Type locality. Contulmo, Prov. Concepción (Chile). Type. Coll. Naturhistorisches Museum, Basel (Switzerland).

Nemadiopsis irretusus: Szymczakowski, 1965: 246.

Nemadiopsis irretusus: Szymczakowski, 1968. Synonymy ( $N$. brevicollis).

Nemadiopsis irretusus: Szymczakowski, 1976: 433.

Nemadiopsis irretusus: Salgado, 1991: 176.

Nemadiopsis fastidiosus: Perreau, 2000: 62.

Nemadiopsis irretusus: Perreau, 2000: 63.

Redescription of male. Length: $3.30-3.90 \mathrm{~mm}$. Colour dark brown. Punctures on head very dense, shallow, often merging.

Antennae 1.56 times as long as pronotum; four segments of funiculus slender and club segments separated (Fig. 7); $6^{\text {th }}-10^{\text {th }}$ segments transverse, $7^{\text {th }}, 9^{\text {th }}$ and $10^{\text {th }}$ becoming progressively shorter and thinner and wider than $11^{\text {th }}$; using the length of the $9^{\text {th }}$ segment as a basis, relative length of each segment from $1^{\text {st }}$ to $11^{\text {th }}$ : 1.30 , $1.13,1.17,0.70,0.70,0.52,1.03,0.30,1.00,0.96,1.30$; ratios of length to width for each segment: $2.73,2.36$, $2.07,1.23,1.00,0.65,0.88,0.39,0.85,0.92,1.50$.

Pronotum transverse, narrower than elytra, 1.50 times as wide as long, widest towards middle; sides rounded and narrower towards the front, posterior angles not protruding; coarse dense punctuation, not granulate. Elytra together 1.60 times as long as wide and 3.08 times as long as the length of pronotum; fine, transverse, irregular striolae; sutural striae whole. Mesosternum with weakly discernible carina in anterior region, slightly more visible in posterior third. First three protarsal segments dilated, the first 1.30 times as wide as the maximum width of tibia; mesotarsi with first segment widened, though only slightly expanded outwards. Genital segment complete (see Salgado, 1991) slightly wider than long (1.10).

Median lobe of aedeagus pointed with slightly concave sides (Fig. 8). Base of basal lamina somewhat shorter than median lobe, mid sternal apex in the form of rounded projection. Robust parameres with expanded apices and internal margins with membranous lamina, surpassing the apex of median lobe; fairly long apical setae inserted near external margin with insertion pores very close together. Fully developed and complex sclerotized armature of internal sac (Fig. 9), with numerous spines on the middle, outer ones are symmetrically set lengthways, with imbricated bases, two large spines differentiated in the ventral median region when the sac is invaginated. Finally, there is a unique arch-shaped structure in the mid basal region.

Diagnosis of female. The female has the same external morphological characteristics as the male, except for the protarsi and mesotarsi, which are not dilated.

Other distinguishing characters are: posterior margin of sternite of VII abdominal segment with slightly protruding arch in the middle, very similar to N. rufimanus; apex of sternite of VIII abdominal segment slightly indented, spiculum ventrale quite wide and sagitta either very weakly discernible or non-existent (Fig. 10). The spermatheca has two well-defined sclerotized lobes and the interconnecting membranous area is long (Fig. 11).

Remarks. The most outstanding characteristics distinguishing this species are the dense, shallow punctures on the head and the transverse $6^{\text {th }}-10^{\text {th }}$ antennal segments; also, the shape of the aedeagus with the complex structures of the internal sac, especially the two large spines and the unique arch shape. 
Discussion. After examining several specimens from different places, variations were observed in certain characters, for example, the male protarsi and the expansion of the antennal segments, the width of the apophysis of the genital segment, as in the spiculum ventrale, the more or less extensive membrane of the internal margin of the parameres, the length of the interconnecting area between the spermathecal lobes, and in particular, the concavity of the margins of the median lobe of the aedeagus.

Bearing this in mind, and after examining specimens (2 males and 2 females) belonging to $N$. irretusus from Río Negro (Argentina) determined by Szymczakowski and at present in the Natural History Museum, Budapest (Hungary), as well as numerous specimens from different places in the provinces of Concepción and Chiloé, it was clear that in some the margins of the median lobe are rectilinear and the spiculum ventrale narrow, whereas in others, the margins are slightly more concave and the spiculum ventrale wide.

According to Szymczakowski (1968), the main difference between $N$. fastidiosus and $N$. irretusus is that the lateral margins of the median lobe are rectilinear, which is a very variable character. Also, some of the differences used by Szymczakowski $(1962,1968)$ to distinguish between these two species are unreliable. I therefore propose that $N$. irretusus is a junior subjective synonym of $N$. fastidiosus.

I must point out that I have not seen specimens of $N$. brevicollis Jeannel, 1962, considered by Szymczakowski (1968) to be synonym of $N$. irretusus.

After examining the "holotype" of Nemadiopsis edwardsi Jeannel, 1936 in the British Museum collection, I must point out it does not differ significantly from the numerous specimens of $N$. fastidiosus. Neither the shape of the male protarsi, which are clearly wider than the tibiae, nor the antennal segments differ. Similarly, the aedeagus and genital segment of $N$. edwardsi have the same structure as in $N$. fastidiosus. In the latter, the inner margins of the parameres are membranous and the pores of the setae are very close together on the external margin. The internal sac has the same structures: two large spines, two rows of imbricated spines and a unique arch-shaped piece. The only specimen described of Nemadiopsis edwardsi in fact belongs to $N$. fastidiosus, and therefore $N$. edwardsi should be considered a junior subjective synonym of Nemadiopsis fastidiosus.

\section{Material examined}

Chile. Aconcagua province: Talauquen, E1 Melón road, 26VI-1982, 1m.-6f., L. Peña leg. Aisén province: Las Juntas, 30XII-1984/29-I-1985, 5m., S. \& J. Peck leg. Cautín province: Parque Nacional Cerro Ñielol, Temuco, 14-30-XII-1982, $1 \mathrm{~m}$. A. Newton \& M. Thayer leg.; 13-XII-1984/12-II-1985, 4m., S \& J. Peck leg.; Parque Nacional Conguillío, Laguna Captrén, 23-XII-1996/5-II-1997, 3m., A. Newton \& M. Thayer leg.; Lago Caburga, 15-XII-1984/19-II-1985, 1m., S. \& J. Peck leg.; Volcán Villarrica, 15-29-XII-1982, 9m.-3f., A. Newton \& M Thayer leg.; 26-XII-1996/3-II-1997, 6m., A. Newton \& M Thayer leg.; Flor del Lago, 14-XII-1984/10-II-1985, 8m., S. \& J. Peck leg. Chiloé province: I. Chiloé, Castro, III-1987, 3m., L. Peña leg.; I. Chiloé, Ahoni Alto, 21-23-II-1988, 30m.-2f., L.
Masner leg.; Chepu, 22-X-1958, 1m., L. Peña leg. Coihaique Province: Dos Lagunas, 23-27-I-1985, 1m., S. \& J. Peck leg. Concepción province: Estero Nonguén, 29-IV-1978, 1m.-1f., T. Cekalovic leg.; San Pedro, 12-XII-1982/2-I-1983, 1m., A. Newton \& M. Thayer leg.; Laguna Posada, 16-VII-1995, 1m., T. Cekalovic leg. Elqui province: Coquimbo, 1-6-XI-1954, $2 \mathrm{~m}$., L. Peña leg.; Llanquihue province: Lago Chapo, 16-27XII-1982, 11m., A. Newton \& M. Thayer leg.; 24-XII-1984/2-II-1985, 5m., S. \& J. Peck leg.; 4-26-I-1997, 3m.-1f., A. Newton \& M. Thayer leg.; Parque Nacional Vicente Pérez Rosales, Ensenada, 2-28-I-1997, 3m., A. Newton \& M. Thayer leg.; P. N. Vicente Pérez Rosales, Volcán Osorno, 3-27I-1997, 6m.-2f., A. Newton \& M. Thayer leg. Magallanes province: Puerto Arenas, 8-14-I-1985, 1m., S. \& J. Peck leg. Malleco province: Angol, 9-XII-1984/16-II-1985, 2m., S. \& J. Peck leg.; Curacautín, 12-XII-1984/16-II-1985, 5m., S. \& J. Peck leg.; Malalcahuello, 13-31-XII-1982, 7m.-3f., A. Newton \& M. Thayer leg.; Manzanar, 19-25-XII-1976, 16m.-3f., S. \& J. Peck leg.; Parque Nacional Nahuelbuta, Cabrería, 21-23-I-1977, 2m.-3f, L. Peña leg.; P. N. Nahuelbuta, Coimallín, 21-XII-96/7-II-1997, 4m., A. Newton \& M. Thayer leg.; Parque Nacional Contulmo, Puren, 11-XII-1984/13-II-1985, 5m.-4f., S. \& J. Peck leg.; Victoria, 26-31-XII-1976, 5m.-2f., S. \& J. Peck leg.; 26-II1988, 1m., L. Masner leg.; Villa Portales, 22-25-XII-1976, 2m.-1f., S. \& J. Peck leg. Ñuble province: Shangrila, 15-17XII-1976, 1m.-2f., S. \& J. Peck leg.; Las Trancas, 10-XII-1982/3-I-1983, 3m.-4f, A. Newton \& M. Thayer leg. Osorno province: Parque Nacional Puyehue, Aguas Calientes, 20-XII1984/8-II-1985, 24m.-5f., S. \& J. Peck leg.; 29-XII-1996/1-II1997, 34m.-6f., A. Newton \& M. Thayer leg.; P. N. Puyehue, Antillanca road, 12-25-XII-1982, 57m.-18f., A. Newton \& M. Thayer leg.; 1-I/1-II-1997, 3m.-1f, A. Newton \& M. Thayer leg.; P. N. Puyehue, Anticura, 19-26-XII-1982, 21m.-3f., A. Newton \& M. Thayer leg.; 1-IX-1983, 1m., L. Peña leg.; 19XII-1984/6-II-1985, 36m.-4f, S. \& J. Peck leg.; 31-XII-1996/30I-1997, 2m., A. Newton \& M. Thayer leg.; Termas de Puyehue, 19-25-XII-1982, 1m., A. Newton \& M. Thayer leg. Palena province: Yelco Chico, Ventisquero, 29-XII-1984/29-I-1985, 22m.-8f., S. \& J. Peck leg. Quillota Province: Parque Nacional La Campana, Olmue, 2-XII-1984, 1m., S. \& J. Peck leg. Talca province: Alto Vilches, 10-13-XII-1976, 18m.-7f., S. \& J. Peck leg. Ultima Esperanza Province: Fiordo Falcón, 17-II-1985, $1 \mathrm{~m}$., A. Ashworth \& M. Gunderson leg. Valdivia province: Parque Nacional Puyehue, Anticura, 19-25-XII-1982, 3m., A. Newton \& M. Thayer leg.; Enco, 5-II-1978, 1m., L. Peña leg.; La Unión, 17-XII-1984/7-II-1985, 13m.-1f., S. \& J. Peck leg.

\section{Nemadiopsis (Nemadiopsis) grossicornis sp. $\mathrm{n}$.}

(Figs 12-16)

Holotype (male), description. Body length: $3.60 \mathrm{~mm}$ (paratypes: $3.50-3.70 \mathrm{~mm}$ ). Oval-shaped, elongate body. Colour uniform, in general, light brown. Pubescence short, golden, fine and prostrate.

Well-defined discrete punctuation on head. Punctures have smaller diameters than distance separating them. Slender maxillary palps, penultimate palpomere not dilated, last one pointed, scarcely longer than previous one.

Antennae long, 1.72 times as long as pronotum (Fig. 12), $7^{\text {th }}$ segment longer and wider; $4^{\text {th }}, 5^{\text {th }}$ and $6^{\text {th }}$ segments of funiculus very short; $1^{\text {st }}, 9^{\text {th }}$ and $11^{\text {th }}$ segments the same size; $2^{\text {nd }}$ segment slightly longer than $3^{\text {rd }} ; 4^{\text {th }}, 5^{\text {th }} 6^{\text {th }}$ and $8^{\text {th }}$ very transverse; $9^{\text {th }}$ and $10^{\text {th }}$ segments almost as long as wide and more robust than $11^{\text {th. }}$ using the length of the $9^{\text {th }}$ 


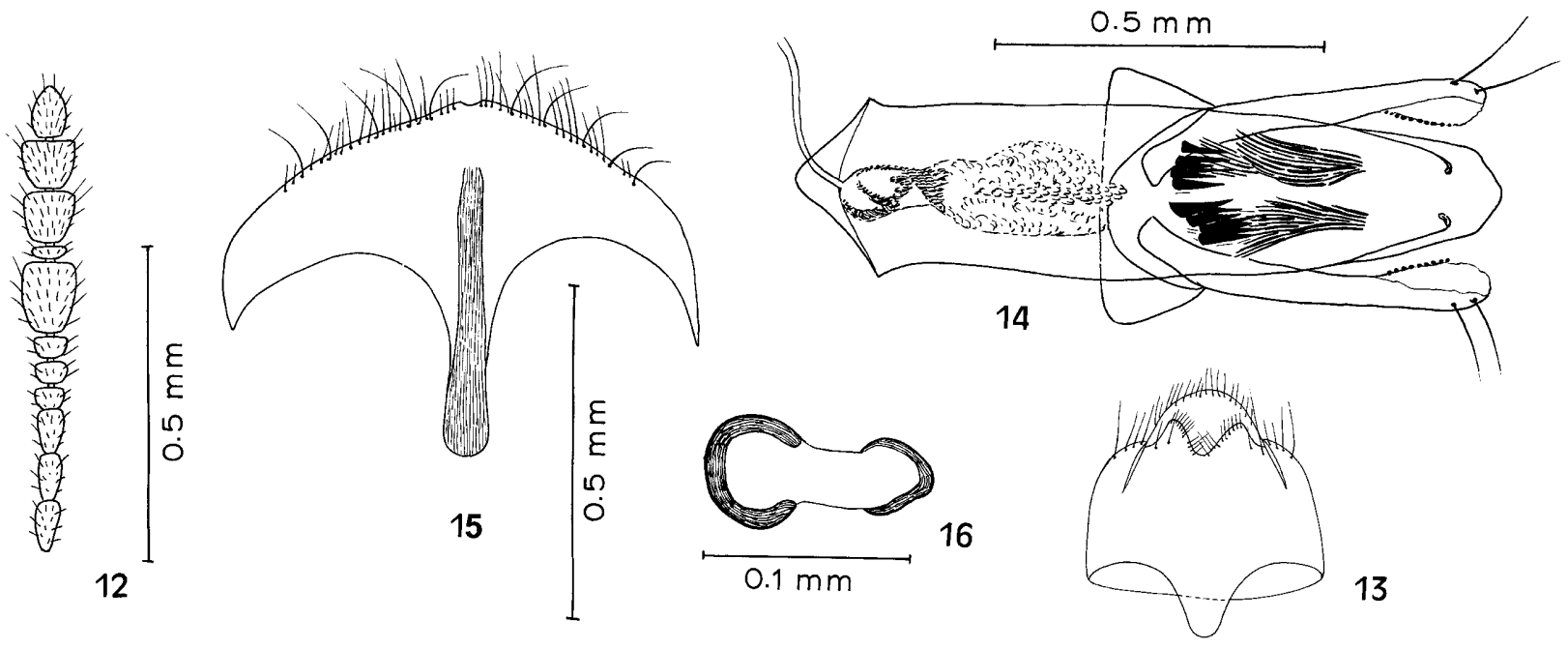

Figs 12-16. Nemadiopsis (Nemadiopsis) grossicornis sp. n. 12 - antenna; 13 - genital segment, ventral view; 14 - aedeagus, ventral view; 15 - spiculum ventrale, ventral view; 16 - spermatheca, dorso-lateral view.

segment as a basis, relative length of each segment from $1^{\text {st }}$ to $11^{\text {th }}: 1.00,0.88,0.75,0.43,0.43,0.38,1.22,0.30$, $1.00,0.97,1.00$; ratios of length to width for each segment: $2.34,2.00,1.63,0.75,0.72,0.60,1.18,0.35,1.00$, $0.96,1.32$.

Pronotum 1.73 times as wide as long, sides uniformly arched, posterior edge wider than anterior edge, widest at middle; small, dense punctures, not granulate. Elytra together 1.69 times as long as wide and 3.42 times as long as the length of pronotum. Carina of mesosternum very fine, slightly raised posteriorly. $1^{\text {st }}$ and $2^{\text {nd }}$ male protarsi expanded, $3^{\text {rd }}$ and $4^{\text {th }}$ weakly expanded, with first tarsomere as wide as the maximum width of tibia (1.00). First segment of intermediate tarsi very slightly dilated and not expanded outwards. Genital segment complete (Fig. 13), clearly wider than long, with short, wide apophysis.

Median lobe of aedeagus wide, apex wide and rounded (Fig. 14). Basal lamina slightly shorter than median lobe, ending in an acute angle in mid apex region. Parameres do not extending beyond apex of median lobe, expanding into large apical clubs with two long setae inserted in clearly separated pores; internal margin of parameres with membranous apex and numerous tiny protuberances resembling microdentation laterally (O.M.: $20 \mathrm{x}$ magnification). Inner sac, with four groups of spines and numerous long, narrow symmetrically arranged fibres in the middle; various scaly areas in basal region.

Diagnosis of female. Shape of body similar to male, except for the narrow protarsi and mesotarsi.

The following characters differ: weakly developed posterior median lobe on sternite of VII abdominal segment: barely marked indention on apex of sternite of VIII segment, long spiculum ventrale, somewhat expanded towards apex, sagitta well defined and surpassing median region of sternite (Fig. 15). Spermathecal lobes small, well-sclerotized, the larger of the two being the apical one (Fig. 16).

\section{Type material}

HOLOTYPE, male, Chile. Osorno province: Parque Nacional Puyehue, $4.0 \mathrm{~km}$ E Anticura, $460 \mathrm{~m}, 40^{\circ} 39.73^{\prime} \mathrm{S}-$ $-72^{\circ} 08.10^{\prime} \mathrm{W}, 31-X I I-1996 / 30-I-1997$, Valdivian rainforest with Saxegothaea, carrion trap, A. Newton \& M. Thayer leg., site 985, FMNH Coll.

PARATYPES. Chile. Cautín province: Volcán Villarrica, $1120 \mathrm{~m}$, site 654, 15-29-XII-1982, Nothofagus dombeyi and Saxegothaea forest with Drimys, carrion pit traps, 3m.-1f. FMNH Coll., and $1 \mathrm{~m}$. Salgado Coll., A. Newton \& M. Thayer leg.; Parque Nacional Conguillío, $11.1 \mathrm{~km}$ SE Laguna Captrén guard station, $1080 \mathrm{~m}, 38^{\circ} 40.05^{\prime} \mathrm{S}-71^{\circ} 37.21^{\prime} \mathrm{W}$, Nothofagus obliqua and $N$. alpina forest with Chusquea, carrion trap, $1 \mathrm{~m}$. FMNH Coll., A. Newton \& M. Thayer leg. Llanquihue province: Lago Chapo, SE side, $\mathrm{Km} 9.9$ on road from Rollizo, 385 $\mathrm{m}, 41^{\circ} 30.63$ 'S-72 $23.98^{\prime} \mathrm{W}, 4-26-\mathrm{I}-1997$, Valdivian rainforest, carrion trap, 1m.-1f. FMNH Coll., and 1f. Salgado Coll., A. Newton \& M. Thayer leg.; Parque Nacional Vicente Pérez Rosales, SW slope Volcán Osorno, Km 10.1 to La Burbuja, 925 $\mathrm{m}, 41^{\circ} 08.30^{\circ} \mathrm{S}-72^{\circ} 32.16^{\prime} \mathrm{W}, 3-27-1997$, Nothofagus dombeyi and Podocarpus nubigena with Valdivian rainforest understory, carrion trap, 1f. FMNH Coll., A. Newton \& M. Thayer leg. Palena province: $70 \mathrm{~km}$ SE Chaiten, Yelco Chico, Ventisquero, $200 \mathrm{~m}, 29-X I I-1984 / 29-I-19985$, mixed beech forest, 3m. FMNH Coll., S. \& J. Peck leg. Osorno province: Parque Nacional Puyehue, Aguas Calientes, 500 m, 20-XII-1984/6-II1985, Pionero Forest Trail, 2m. FMNH Coll. and 2m. MNNC Coll., S. \& J. Peck leg.; P. N. Puyehue, Anticura, 500 m, 19XII-1984/6-II-1985, Repucura Forest Trail, 1m. FMNH Coll., S. \& J. Peck.; P. N. Puyehue, Antillanca road, $7.2 \mathrm{~km}$ above Aguas Calientes, $660 \mathrm{~m}, 40^{\circ} 45.55^{\prime} \mathrm{S}-72^{\circ} 17.82^{\prime} \mathrm{W}, 29-X I I-1996 / 1-\mathrm{II}-$ 1997, Valdivian rainforest with Saxegothaea and Chusquea, carrion trap, 1m.FMNH Coll., A. Newton \& M. Thayer leg.; P. N. Puyehue, Antillanca road, 720 m, 18-24-XII-1982, Nothofagus spp. forest, 1m.-1f., A. Newton \& M. Thayer leg.; P. N. Puyehue, Antillanca road, 845 m, 18-24-XII-1982, Nothofagus and Saxegothaea forest, 1m. FMNH Coll., A. Newton \& M. Thayer leg.; P. N. Puyehue, Antillanca road, $980 \mathrm{~m}$, $40^{\circ} 46.85^{\prime} \mathrm{S}-72^{\circ} 13.03^{\prime} \mathrm{W}, 1-\mathrm{I} / 1-\mathrm{II}-1997$, Nothofagus pumilio forest with Chusquea, carrion trap, 2m. FMNH Coll., A. Newton \& M. Thayer leg.; P. N. Puyehue, Antillanca road, 965 m, 18-25-XII-1982, Nothofagus pumilio forest, 3m.-1f. FMNH Coll., A. Newton \& M. Thayer leg. Valdivia province: $34 \mathrm{~km}$ 

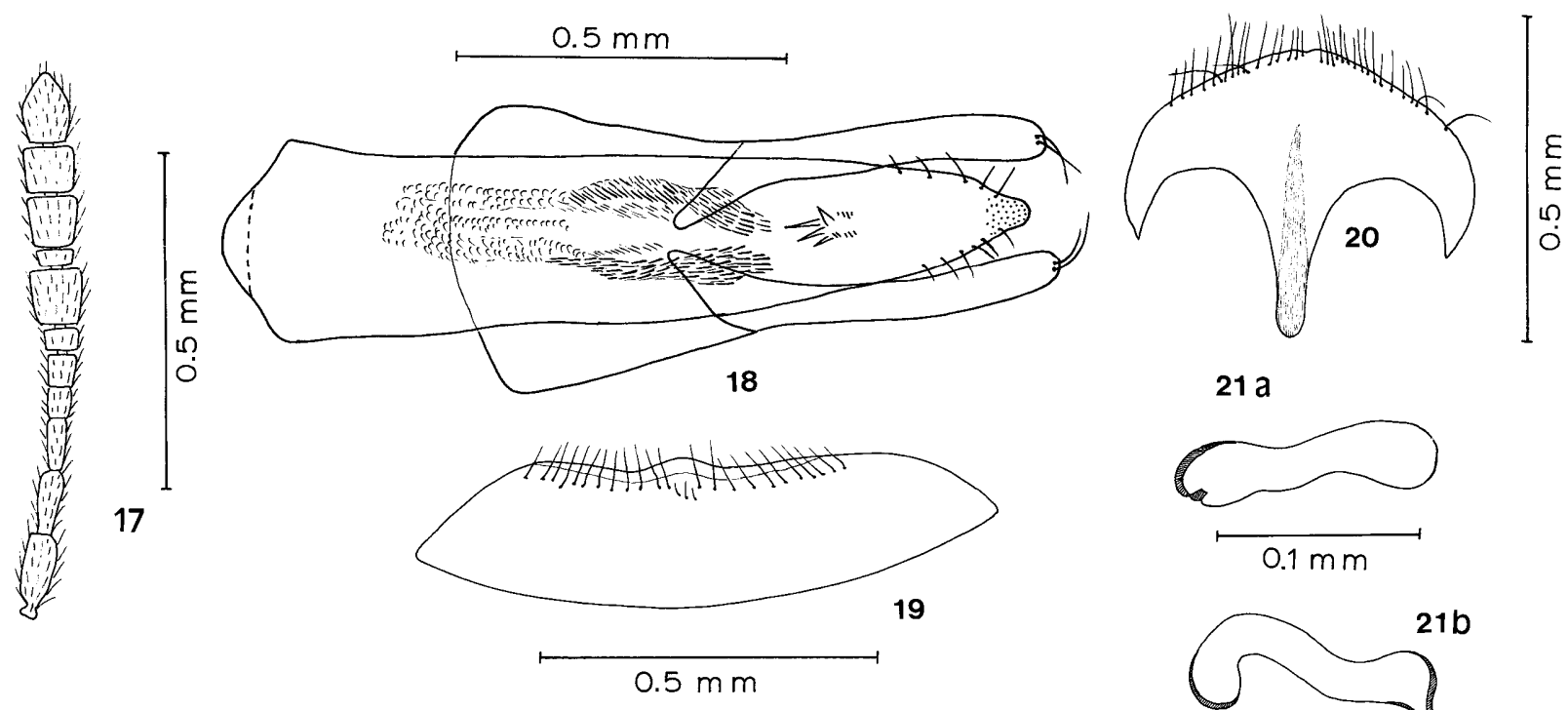

21 a

Figs 17-21. Nemadiopsis (Nemadiopsicus) barbarae. 17 - antenna; 18 - aedeagus, ventral view; 19 - VII abdominal segment; 20 - spiculum ventrale, ventral view; 21 - spermatheca, a - dorso-lateral view; b - lateral view.

WNW La Unión, 17-XII-1984/7-II-1985, mixed evergreen forest, 3 m. FMNH Coll. and $1 \mathrm{~m}$. Salgado Coll., S. \& J. Peck leg.

Discussion. This species is easily distinguishable from others belonging to the genus by the shape of the antennal segments, the $7^{\text {th }}$ of which is very robust, and the $4^{\text {th }}, 5^{\text {th }}$ and $6^{\text {th }}$ very small segments of the funiculus. The most significant differences are in the overall shape of the aedeagus, which is not pointed at the apex, the parameres with numerous small teeth on the internal margin and the separate insertion pores, as well as the internal sac with 4 groups of elongated fibres and spines.

Etymology. From the Latin grossus (thick) and cornus (horn), refering to one of the most significant differentiating characteristics, the robustness of the $9^{\text {th }}$ and $10^{\text {th }}$ segments, and in particular, the $7^{\text {th }}$ antennal segment.

\section{Subgenus Nemadiopsicus subgen. $\mathbf{n}$.}

Type species. Nemadiopsis barbarae Szymczakowski, 1968

Diagnosis. The most important characters of the subgenus are: the transverse antennal segments, or at least the $6^{\text {th }}$ and $8^{\text {th }}$ (Figs 17, 22 and 27); the genital segment as long as or slightly longer than wide (Figs 23 and 28); the insertion pores of the two setae on the parameres very close together; lateral margins of the median lobe with setae; basal lamina of aedeagus longer than median lobe (Figs 18, 24 and 29); median posterior margin of sternite of VII abdominal segment of females with a differentiated lobe (Figs 19 and 30); membranous sac-shaped spermatheca (Figs 21, 26 and 32).

The subgenus can be defined by two basic characters: the lateral margins of median lobe bearing setae and the membranous sac-shaped spermatheca.

Etymology. The subgenus Nemadiopsicus means that "it belongs to Nemadiopsis", since this subgenus is formed by the prefix "Nemadiop", from the term Nemadiopsis and the Greek suffix "sicus", which means "belonging to".

\section{Nemadiopsis (Nemadiopsicus) barbarae Szymczakowski, 1968}

(Figs 17-21)

Nemadiopsis ? fastidiosus: Szymczakowski, 1965: 246.

Nemadiopsis barbarae Szymczakowski, 1968: 23.

Type locality. El Puelo, Chubut (Argentina). Type. Coll. Museum of Natural History Budapest (Hungary).

Nemadiopsis barbarae: Salgado, 1991: 177.

Nemadiopsis barbarae: Perreau, 2000: 62.

Redescription of male. Length: $3.25-3.55 \mathrm{~mm}$. Colour dark brown. Head very clearly punctured with strong, deep, distinct punctures. Antennae 1.52 times as long as pronotum (Fig. 17), $1^{\text {st }}$ and $11^{\text {th }}, 2^{\text {nd }}$ and $3^{\text {rd }}, 4^{\text {th }}$ and $5^{\text {th }}$ segments respectively, of equal length; $7^{\text {th }}$ segment longer than $9^{\text {th }}$ and $10^{\text {th }}$, which are equal in size; $7^{\text {th }}, 9^{\text {th }}, 10^{\text {th }}$ and $11^{\text {th }}$ of same width; $6^{\text {th }}$ and $8^{\text {th }}$ segments transverse; using the length of the $9^{\text {th }}$ segment as a basis, relative length of each segment from $1^{\text {st }}$ to $11^{\text {th }}: 1.32,1.18,1.18 .0 .79,0.79$, $0.59,1.23,0.39,1.00,1.00,1.32$; ratios of length to width for each segment: $2.40,2.14,2.14,1.43,1.43,0.93,1.32$, $0.57,1.08,1.08,1.44$.

Pronotum transverse, 1.56 times as wide as long, sides feebly rounded and not sinuate. Strong, somewhat granulate punctures. Elytra together 1.64 times as long as wide and 3.24 as long as the length of pronotum. Strioles transverse, strong and almost perpendicular to suture. Mesosternum with fine carina on midline, slightly more pronounced on posterior third. Male protarsi expanded, first segment wider than greatest width of tibia (1.3); intermediate tarsi with first segment weakly dilated and slightly expanded outwards. Genital segment slightly longer than wide (see Szymczakowski, 1968), with short, broad sternal apophysis.

Median lobe of aedeagus lanceolate, narrowing slightly at apex, which has micropunctuation (O.M.: $20 \times$ magnification) and 3 to 6 , normally 3 , short setae on lateral 
margins (Fig. 18). Elongate tubulose basal lamina, longer than median lobe, margin of apex in the form of an arch with wide edge. Robust, wide parameres, completely sclerotized surpassing apex of median lobe; two closely inserted apical setae. Lamina of tegmen well-developed and enclosing basal lamina ventrally and dorsally. Internal sac with small spines on mid region of median lobe and on basal region of lamina base, two long lateral rows of spines on anterior region. Arch-shaped, acute scaly areas along the middle.

Diagnosis of female. The external morphology of the female is very similar to that of the male, but the pro- and mesotarsi are not dilated.

The most important characteristics are the sternite of the VII abdominal segment has a well-developed lobe on the median margin of the apex (Fig. 19); apex of tergite and sternite of VIII abdominal segment rounded or slightly cloven, narrow spiculum ventrale with diffuse sagitta penetrating sternite (Fig. 20). The membranous spermatheca is in the shape of an elongated sac of uniform width (Fig. 21a, b).

Remarks. As indicated by Szymczakowski (1971), though generally smaller and the segments of the antennal club are not elongated, or the male protarsi as expanded, the morphology of this species is very similar to that of Nemadiopsis trichophorus. The most significant differences are, undoubtedly, the general structure of the aedeagus, the spermatheca and the VIII abdominal sternite of the female. The paratypes in the Natural History Museum collection, Budapest (Hungary), and specimens from the type locality, El Puelo (Argentina), lack the furrow on the dorsal face of the median lobe mentioned by Szymczakowski (1968), but do have marginal setae, of great significance but not mentioned by this author.

\section{Material examined}

Chile. Cautín province: Parque Nacional Villarrica, Volcán Villarica, 15-29-XII-1982, 1m., A. Newton \& M. Thayer leg.; 27-XII-1996/3-II-1997, 5 m., A. Newton \& M. Thayer; Parque Nacional Villarrica, Pucón, 15-XII-84/10-II-85, 1 m., S. \& J. Peck leg. Parque Nacional Conguillío, Laguna Captrén, 23-XII1996/5-II-1997, 1m., A. Newton \& M. Thayer leg. Malleco province: Malalcahuello, 19-31-XII-1976, 1m., S. \& J. Peck leg.; 13-31-XII-1982, 9m.-2f., A. Newton \& M. Thayer leg.; 12XII-1984/16-II-1985, 1m., S. \& J. Peck leg.; Manzanar, 19-25XII-1976, 5m.-2f., S. \& J. Peck leg.; Parque Nacional Nahuelbuta, Coimallín area, 21-XII-96/7-II-97, 1m., A. Newton \& M. Thayer leg. Osorno province: Termas de Puyehue, 1925-XII-1982, 1f., A. Newton \& M. Thayer leg. Nuble province: Las Trancas, 13-17-XII-1976, 2m., S. \& J. Peck leg.; 10-XII1982/23-I-1983, 7m.-2f., A. Newton \& M. Thayer leg. Talca province: Alto Vilches, 10-13-XII-1976, 2m., S. \& J. Peck leg. Valdivia province: La Unión, 17-XII-1984/7-II-1985, 1m., S \& J. Peck leg.

Argentina. Bahía S. Sebastián, Cerrillos, 21-IV-1971, 1m., O.S. Flint \& O.F. Nevel leg.

\section{Nemadiopsis (Nemadiopsicus) trichophorus Szymczakowski, 1971}

(Figs 22-26)

Nemadiopsis trichophorus Szymczakowski, 1971: 405.
Type locality. Nahuelbuta, Prov. Arauco (Chile). Type. Coll. Zoologische Staatssammlung, München (Germany).

Nemadiopsis trichophorus: Perreau, 2000: 63.

Redescription of male. Length: $3.35-3.65 \mathrm{~mm}$. Body elongate and oval-shaped. Colour generally light brown.

Head with very clear, deep, distinct punctures. Antennae long with easily discernible segments, 1.65 times as long as pronotum (Fig. 22); $4^{\text {th }}, 5^{\text {th }}$ and $6^{\text {th }}$ segments of almost equal size; $6^{\text {th }}$ and $8^{\text {th }}$ transverse; $7^{\text {th }}$ clearly longer than the $9^{\text {th }}$ and $10^{\text {th }}$ segments; $7^{\text {th }}, 9^{\text {th }}$ and $10^{\text {th }}$ segments of equal width; using the length of the $9^{\text {th }}$ segment as a basis, relative length of each segment from $1^{\text {st }}$ to $11^{\text {th }}: 1.32,1.07,1.18,0.64,0.65,0.63,1.18,0.35$, $1.00,0.89,1.32$; ratios of length to width for each segment: $2.62,2.13,2.37,1.22,1.10,0.95,1.42,0.50,1.20$, $1.13,1.84$.

Pronotum 1.54 times as wide as long, uniformly arched sides, maximum width near middle. Punctures strong, dense and somewhat granulate. Elytra elongate, 1.60 times as long as wide and 3.00 times as long as the length of pronotum. Strioles transverse, easily visible and quite uniform. Mesosternum with fine carina on midline, somewhat raised on posterior third. Anterior tarsi with first segment very rounded and much wider than maximum width of tibiae (1.57); $2^{\text {nd }}$ and $3^{\text {rd }}$ segments dilated and cordiform. Intermediate tarsi with first segment dilated and expanded outwards. Genital segment resembling that of other species belonging to the genus, somewhat longer than wide, sternal apophysis short and broad (Fig. 23).

Median lobe of aedeagus pointed apically, with 5 or more short, fine marginal setae, of decreasing length (Fig. 24). Basal lamina much longer than median lobe, ventral region of apex in the shape of a gently arched lobe. Parameres completely sclerotized, very sclerotized internal basal regions, wide, flattened and clearly surpassing apex of median lobe, apex rounded with micropunctuation and two rather short setae very closely inserted near the middle of the apex. Internal sac with two long rows of lateral spines, with a scaly area in between.

Diagnosis of female. Generally more robust than the male, though the antennal club has shorter segments, and the pro- and mesotarsi are narrower.

The most important distinguishing characters are as follows: sternite of VII abdominal segment with welldefined median lobe on posterior margin; sternite of VIII abdominal segment with narrow spiculum ventrale and expanded sagitta reaching mid region (Fig. 25). Membranous sac-like spermatheca dilated basally and narrow at the apex (Fig. 26).

Remarks. The main distinguishing characters of males are the $7^{\text {th }}$ antennal segment, clearly longer and more robust than the $9^{\text {th }}$ and $10^{\text {th }}$; the structures of the aedeagus with the narrow, pointed apex of the median lobe, at least 5 marginal setae and parameres much longer than the median lobe. The distinguishing features of females include the well-defined posterior median lobe on the sternite of the $7^{\text {th }}$ abdominal segment, the shape of the spiculum ventrale and the spermatheca. All these characters make the species easy to identify. 

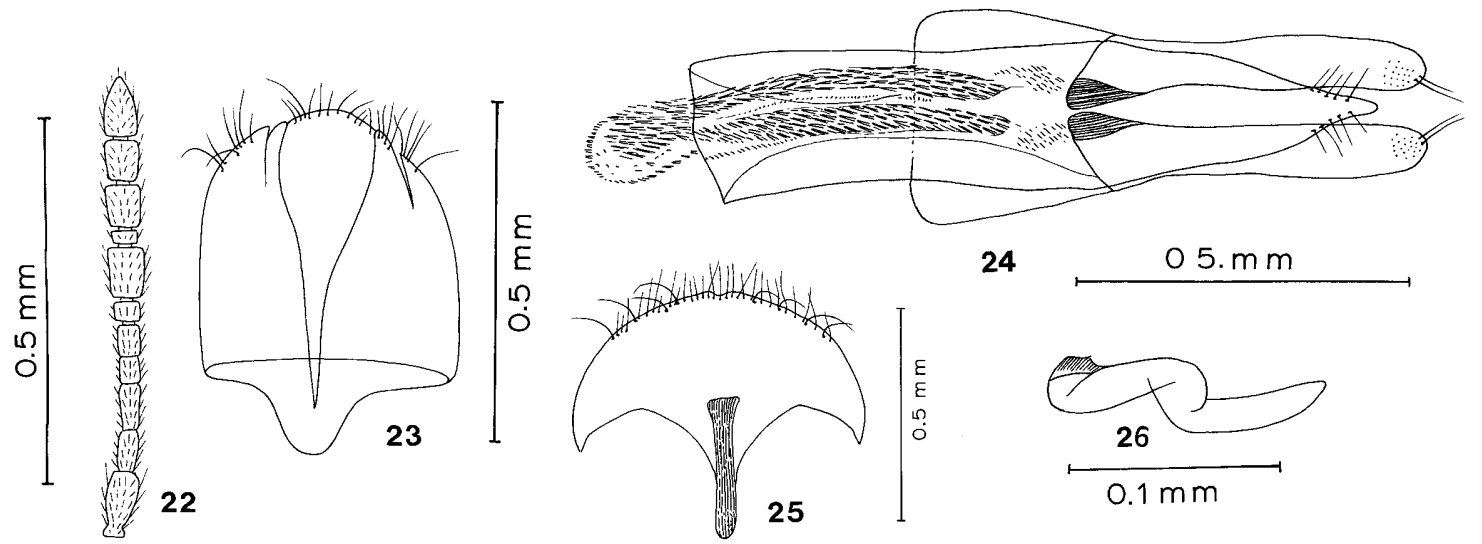

Figs 22-26. Nemadiopsis (Nemadiopsicus) trichophorus. 22 - antenna; 23 - genital segment, ventral view; 24 - aedeagus, ventral view; 25 - spiculum ventrale, ventral view; 26 - spermatheca, lateral view.

\section{Material examined}

Chile. Cautín province: Parque Nacional Conguillío, Laguna Captrén, 23-XII-1996/5-II-1997, 2m., A. Newton \& M. Thayer leg.; Parque Nacional Villarrica, Volcán Villarrica, 27-XII-1996/3-II-1997, 1 m., A. Newton \& M. Thayer leg. Malleco province: Victoria, 26-31-XII-1976, 1m., S. \& J. Peck leg.; Parque Nacional Nahuelbuta, Coimallín, 21-XII-1996/7-II-1997, 3 m., A. Newton \& M. Thayer leg. Concepción province: S San Pedro, 12-XII-1982/2-I-1983, 1m., A. Newton \& M. Thayer leg. Llanquihue province: Lago Chapo, 24-XII-1984/2-II-1985, 5m.-1f., S. \& J. Peck leg.; 16-27-XII-1982, 3m., A. Newton \& M. Thayer leg. Nuble province: Las Trancas, 10-XII-1982/5-I1983, 3m., A. Newton \& M. Thayer leg.; 13-17-XII-1976, 2m., S. \& J. Peck leg. Osorno province: Parque Nacional Puyehue, Anticura, 19-XII-1984/6-II-1985, 2m., S. \& J. Peck leg. Palena province: Yelco Chico, Ventisquero, 29-XII-1984/29-I-1985, 7m.-1f., S. \& J. Peck leg. Talca province: Alto Vilches, 10-13XII-1976, 2m.-3f., S. \& J. Peck leg. Valdivia province: La Unión, 17-XII-1984 / 7-XII-1985, 1m., S. \& J. Peck leg.

\section{Nemadiopsis (Nemadiopsicus) rotundatus sp. $\mathrm{n}$.}

(Figs 1, 27-32)

Holotype (male), description. Body length: $3.70 \mathrm{~mm}$ (length of paratypes: $3.60-3.90 \mathrm{~mm}$ ). Elongated oval shaped body. Colour dark brown. Short, fine prostrate pubescence (Fig. 1).

Head with strong dense, distinct punctures; interspaces larger than punctures. Penultimate segment of maxillary palps not dilated and of same length as the last, which is strongly pointed. Antennae 1.47 times as long as pronotum (Fig. 27); $1^{\text {st }}, 3^{\text {rd }}$ and $11^{\text {th }}, 2^{\text {nd }}$ and $7^{\text {th }}, 4^{\text {th }}$ and $5^{\text {th }}, 9^{\text {th }}$ and $10^{\text {th }}$ segments, of equal length; $9^{\text {th }}$ and $10^{\text {th }}$ segments of equal width, slightly wider than $11^{\text {th }}, 5^{\text {th }}, 6^{\text {th }}, 8^{\text {th }}, 9^{\text {th }}$ and $10^{\text {th }}$ segments transverse; using the length of the $9^{\text {th }}$ segment as a basis, relative length of each segment from $1^{\text {st }}$ to $11^{\text {th }}: 1.40,1.22,1.38,0.80,0.80,0.65,1.22,0.40,1.00$, $1.00,1.40$; ratios of length to width for each segment: $2.00,1.74,1.97,1.14,0.98,0.82,1.04,0.48,0.96,0.96$, 1.56 .

Pronotum transverse, 1.60 times as wide as long, sides weakly rounded, narrower at front than back; strong, granulate punctures, with dense, transverse striae. Elytra wider than pronotum, together 1.65 times as long as wide and 3.26 times as long as length of pronotum. Mesosternum with well-defined carina along midline, somewhat raised on posterior region. Male protarsi expanded, first protarsomere very dilated, wider than maximum width of tibia (1.57); $2^{\text {nd }}$ to $4^{\text {th }}$ segments dilated and cordiform, becoming progressively more narrow. Mesotarsi with first segment weakly dilated and not expanded outwards. Genital segment complete, as long as wide (Fig. 28), short, broad sternal apophysis.

Aedeagus with median lobe strongly expanded in median region and pointed at apex, bearing 5 to 9 very small marginal setae (O.M.: $20 \times$ magnification), anterior 2 or 3 somewhat longer (Fig. 29). Apex of median lobe and internal apex of parameres with clearly visible micropunctuation (O.M.: $20 \times$ magnification). Basal lamina almost twice as long as median lobe, apical margin gently arched. Robust parameres with internal basal regions strongly sclerotized, surpassing apex of median lobe; broad, rounded club with two fairly long closely inserted setae. Inner sac without teeth or spines, widely archshaped structure in laminar base formed by long sclerotized fibres, and behind it, numerous spines and scales.

Diagnosis of female. The external morphology of female is very similar to that of the male, in both body shape and structure of the antennal segments, but lacks dilated pro- and mesotarsi.

The most outstanding characters are: the pointed, fullyformed lobe in the posterior median region of the sternite of the VII abdominal segment (Fig. 30); the slight notch in the mid apical region of the sternite of the VIII abdominal segment and the expanded spiculum ventrale in the anterior region, with a slightly marked sagitta in the median region of the sternite (Fig. 31). The sacciform spermatheca is very elongate and membranous (Fig. 32).

\section{Type material}

HOLOTYPE, male, Chile. Nuble province: Las Trancas, 19.5 km ESE Recinto, 1250 m, 10-XII-1982/3-I-1983, Nothofagus spp. forest, human dung baited pitfall traps, A. Newton \& M. Thayer leg., site 647, FMNH Coll.

PARATYPES. Chile. Cautín province: $15 \mathrm{~km}$ NE Villarrica, Flor del Lago, 300 m, 14-XII-1984/10-II-1985, Nothofagus forest, 2m. FMNH Coll. and 1m. Salgado Coll., S. \& J. Peck leg. 


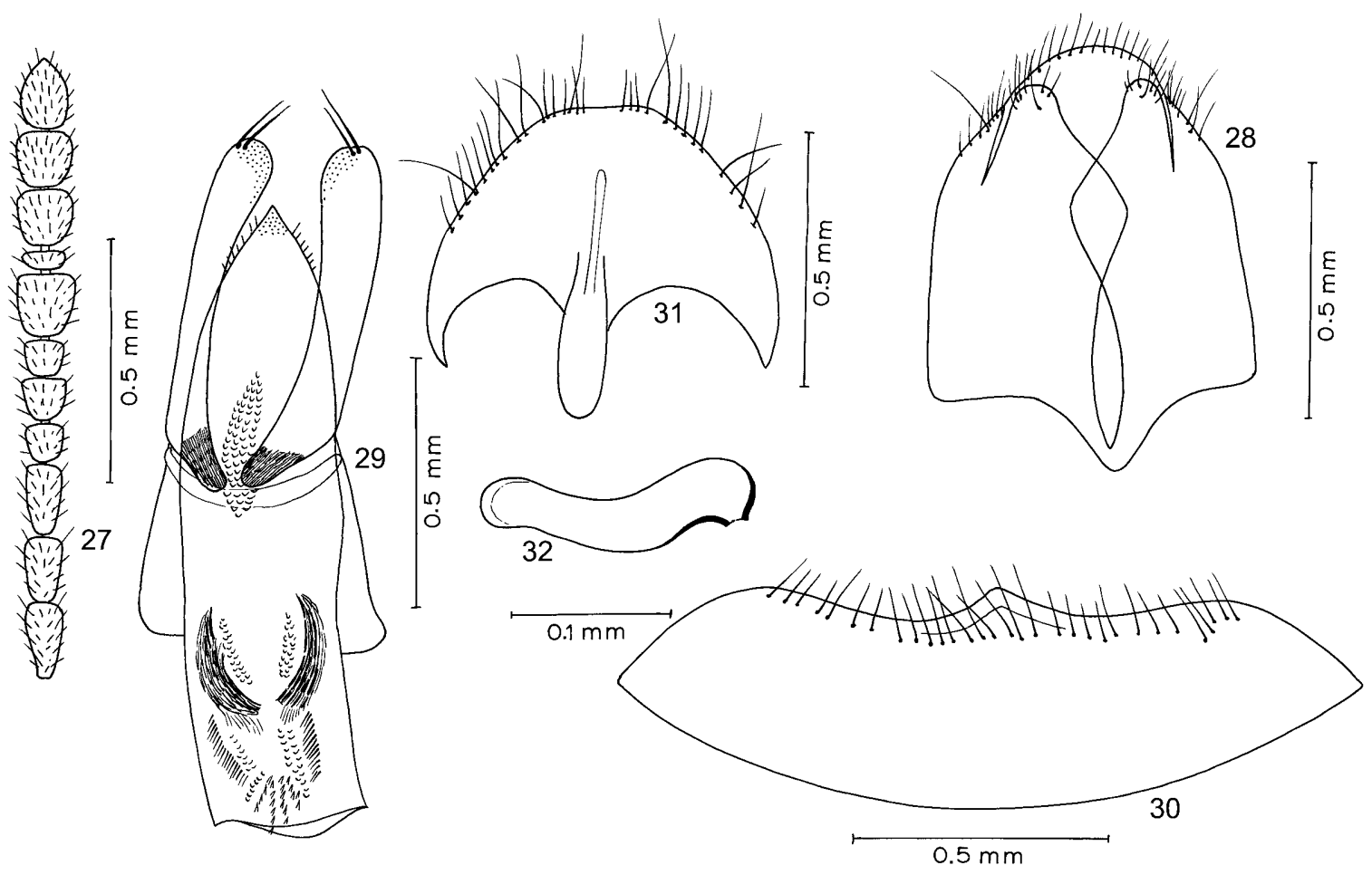

Figs 27-32. Nemadiopsis (Nemadiopsicus) rotundatus sp. n. 27 - antenna; 28 - genital segment, ventral view; 29 - aedeagus, ventral view; 30 - VII abdominal segment; 31 - spiculum ventrale, ventral view; 32 - spermatheca, lateral view.

Llanquihue province: Lago Chapo, $34 \mathrm{~km}$ E Pto. Montt, 300 m, 24-XII-1984/2-II-1985, Nothofagus forest, $3 \mathrm{~m}$. FMNH Coll., S. \& J. Peck leg. Malleco province: $6.5 \mathrm{~km}$ E Malalcahuello, $1080 \mathrm{~m}$, site 651, 13-31-XII-1982, Nothofagus dombeyi forest with Chusquea, window trap, 2m. FMNH Coll., A. Newton \& M. Thayer leg.; $12 \mathrm{~km}$ E Malalcahuello, $1350 \mathrm{~m}$, site 650, 13-31-XII-1982, Nothofagus dombeyi and Araucaria forest, carrion baited pit traps, 3m. FMNH Coll. and $1 \mathrm{~m}$. Salgado Coll., A. Newton \& M. Thayer leg.; $20 \mathrm{~km}$ E Manzanar, 1100 m, 19-25-XII-1976, carrion trap, 1f., FMNH Coll., S. \& J. Peck leg. Nuble province: Las Trancas, $19.5 \mathrm{~km}$ ESE Recinto, $1250 \mathrm{~m}, 10-\mathrm{XII}-1982 / 3-\mathrm{I}-1983$, Nothofagus spp. forest, human dung baited pitfall traps, 2m. FMNH Coll., A. Newton \& M Thayer leg.; Las Trancas, $22.7 \mathrm{~km}$ ESE Recinto, $1330 \mathrm{~m}, 10-$ XII-1982/3-I-1983, Nothofagus spp. forest, human dung baited pitfall traps, 1m.-3f. FMNH Coll., 1m.-1f. MNNC and 1f. Salgado Coll., A. Newton \& M. Thayer leg.; Shangrila, $75 \mathrm{~km} \mathrm{E}$ Chillán, $1650 \mathrm{~m}, 15-17-X I I-1976$, carrion traps, 1m. FMNH Coll., S. \& J. Peck leg. Osorno province: Parque Nacional Puyehue, Anticura, 500 m, 19-XII-1984/6-II-1985, Repucura forest trail, 1f. FMNH Coll., S. \& J. Peck leg.; P. N. Puyehue, Aguas Calientes, $500 \mathrm{~m}, 20-X I I-1984 / 6-I I-1985$, Pionero forest trail, 2m.-1f. FMNH Coll., S. \& J. Peck leg. Quillota province: Parque Nacional La Campana, Olmue, 2-XII-1984, hygrophilous forest leaf litter, Berlesse, 2m. FMNH Coll., S. \& J. Peck leg. Talca province: Alto Vilches, $1300 \mathrm{~m}, 110-13-X I I-1976$, carrion traps, 1m. FMNH Coll., S. \& J. Peck leg. Valdivia province: $34 \mathrm{~km}$ WNW La Unión, $700 \mathrm{~m}, 17-\mathrm{XII}-1984 / 7-\mathrm{II}-$ 1985, mixed evergreen forest, 1m. FMNH Coll., S.\& J. Peck leg.

Discussion. This species is easily distinguished from all other closely related species by the characters of the aedeagus, particularly the wide shape of the median lobe, the small marginal setae (O.M.: $20 \times$ magnification), and the armature of the inner sac, with sclerotized fibres forming an arch. The closest species is, undoubtedly, $N$. barbarae, because of the head punctures and the shape of the antennae, although the antennal segments are comparatively wider in the new species and the male protarsi are more dilated; the genital segment, VII and VIII abdominal segments of females and general shape of the spermatheca are all very similar. The new species resembles $N$. trichophorus, especially in the antennal segments, genital segment, strongly expanded male protarsi and the VII and VIII abdominal segments of females.

Etymology. The species name come from shape of some of the most important characters of the new species, the rounded shape of the median lobe, the parameres and male protarsi.

\section{Subgenus Nemadiopsella subgen. $n$.}

Type species. Nemadiopsis (Nemadiopsella) curvipes sp. $\mathrm{n}$.

Diagnosis. Punctures on head and pronotum fine, numerous and clearly visible. Antennae very long, segments of club clearly separated (Fig. 33). Male metatrochanters strongly pointed and somewhat curved (Fig. 35). Basal lamina shorter than median lobe, very long robust parameres with membranous apex and internal margin bearing microsetae (Fig. 37). Membranous, very irregular spermatheca.

The main characters differentiating this new subgenus are: parameres bearing setae on internal margin and the membranous, irregular spermatheca.

Etymology. The subgenus Nemadiopsella indicates that "it is found in the same area or place as Nemadiopsis", as this subgenus is formed by the prefix "Nemadiop, from the term Nema- 


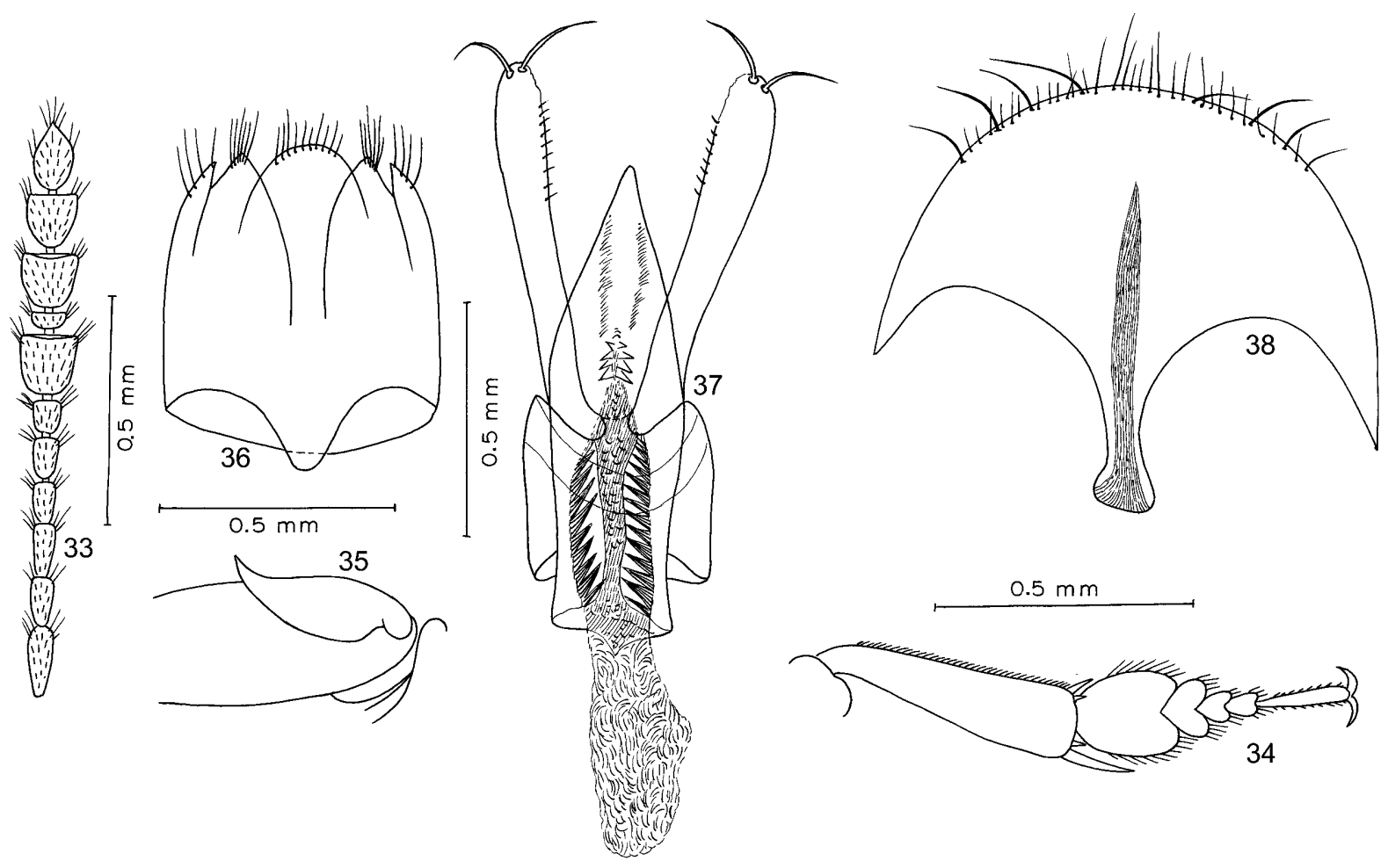

Figs 33-38. Nemadiopsis (Nemadiopsella) curvipes sp. n. 33 - antenna; 34 - anterior tarsi and tibia; 35 - right metatrochanter; 36 - genital segment, ventral view; 37 - aedeagus, dorsal view; 38 - spiculum ventrale, ventral view.

diopsis and the Latin suffix "sella", which means "place or area".

\section{Nemadiopsis (Nemadiopsella) curvipes sp. $\mathrm{n}$.}

(Figs. 33-38)

Holotype (male), description. Body length: $4.35 \mathrm{~mm}$ (paratypes: $4.20-4.50 \mathrm{~mm}$ ). Colour dark brown, mouth parts, $1^{\text {st }}-3^{\text {rd }}$ antennal segments and tarsi dark brown.

Head bearing very dense, shallow merging punctures. Long antennae, 1.87 times as long as pronotum, segments of funiculus separated and club segments strongly separated (Fig. 33); $2^{\text {nd }}, 3^{\text {rd }}, 9^{\text {th }}$ and $10^{\text {th }}, 4^{\text {th }}$ and $5^{\text {th }}, 1^{\text {st }}$ and $11^{\text {th }}$ segments respectively, of equal length; $8^{\text {th }}, 9^{\text {th }}$ and $10^{\text {th }}$ segments transverse; $7^{\text {th }}$ slightly wider than $9^{\text {th }}$ and $10^{\text {th }}$ and these slightly longer than $11^{\text {th }}$; using the length of the $9^{\text {th }}$ segment as a basis, relative length of each segment from $1^{\text {st }}$ to $11^{\text {th }}: 1.37,0.99,1.01,0.78,0.78,0.63,1.20$, $0.32,1.00,1.00,1.40$; ratios of length to width for each segment: $2.63,2.00,2.00,1.52,1.50,1.12,1.08,0.52$, $0.87,0.93,1.75$.

Pronotum markedly narrower than elytra, 1.35 times as wide as long, almost parallel sides, very weakly rounded and weakly narrowing towards base: dense, granulate punctures. Elytra long and convex, 1.65 times as long as wide and 3.30 times as long as the length of pronotum; strioles fine and irregular, perpendicular to sutural stria, which is whole and easily visible. Mesosternal carina scarcely discernible anteriorly, weakly defined posteriorly. Anterior tarsi with first three segments dilated (Fig. 34), first wider than greatest width of tibia (1.25), and slightly longer than wide; intermediate tarsi with first segment weakly widened and slightly expanded outwards. Elongated metatrochanters, very pointed and generally curved towards apex (Fig. 35). Genital segment complete, longer than wide, short, broad sternal apophysis (Fig. 36).

Aedeagus with median lobe subtriangular and a very acuminated apex (Fig. 37). Basal lamina shorter than median lobe, with short protuberance on median margin of apex. Parameres very long and robust, easily surpassing apex of median lobe, two fairly long, clearly separated setae at apex; internal margin with membranous apex and 7-10 microsetae (O.M.: $20 \times$ magnification) on median region. Internal sac bearing two long rows of imbricated, robust teeth and with numerous scaly areas all over the basal, median and apical regions.

Diagnosis of female. The female has the same external morphological characteristics as the male, nevertheless the female is generally more robust, lacks dilated protarsi and mesotarsi, and the metafemurs, have a pointed apex, are shorter and never curved.

Shape of posterior edge of sternite of VII abdominal segment, a wide arch. Apex of sternite of VIII abdominal segment arch-shaped, spiculum ventrale long and narrow, with spatulate apex and median region bearing discernible sagitta (Fig. 38). Membranous spermatheca, irregular sac shape, globose, always difficult to define.

\section{Type material}

HOLOTYPE, male, Chile. Llanquihue province: Lago Chapo, 34 km E Pto. Montt, 300 m, 24-XII-1984/2-II-1985, Nothofagus forest, carrion trap, S. \& J. Peck leg., FMNH Coll.

PARATYPES. Chile. Cautín province: Parque Nacional Conguillío, $11.1 \mathrm{~km}$ SE Laguna Captrén, $1080 \mathrm{~m}, 38^{\circ} 40.05^{\prime} \mathrm{S}$ - 
71'37.21'W, 23-XII.1996/5-II-1997, Nothofagus obliqua and $N$. alpina forest with Chusquea, carrion trap, $2 \mathrm{~m}$.-3f. FMNH Coll. and 1f., Salgado Coll, A. Newton \& M. Thayer leg. Llanquihue province: Lago Chapo, $34 \mathrm{~km} \mathrm{E}$ Pto. Montt, $300 \mathrm{~m}$, 24-XII-1984/2-II-1985, Nothofagus forest, carrion trap, 15m.-3f. FMNH Coll., 3m.-2f. MNNC and 1m. Salgado Coll., S. \& J. Peck leg. Malleco province: $20 \mathrm{~km}$ E Manzanar, $1100 \mathrm{~m}, 19-$ 25-XII-1976, 2m. FMNH Coll., S. \& J. Peck leg.; $40 \mathrm{~km} \mathrm{E}$ Curacautín, $1500 \mathrm{~m}, 12-\mathrm{XII}-1984 / 16-I I-1985$, Nothofagus and Araucaria forest, Malaise traps, 2m.-2f. FMNH Coll., S. \& J. Peck leg.; Parque Nacional Nahuelbuta, Coimallín area, $8.2 \mathrm{~km}$ NW Los Portones, $1260 \mathrm{~m}, 37^{\circ} 48.21^{\prime} \mathrm{S}-73^{\circ} 00.89^{\prime} \mathrm{W}, 21-\mathrm{XII}-$ 1996/7-II-1997, Nothofagus spp. and Araucaria araucana forest, carrion trap, 2m.-4f. FMNH Coll. and 1f. Salgado Coll., A. Newton \& M. Thayer leg. Osorno province: Parque Nacional Puyehue, Aguas Calientes, 500 m, 20-XII-1984/6-II1985, Pionero forest trail, 2m. FMNH Coll., S. \& J. Peck leg. Valdivia province: $34 \mathrm{~km}$ WNW La Unión, $700 \mathrm{~m}, 17-X I I-$ 1984/7-II-1985, mixed evergreen forest, 8m.-3f. FMNH Coll. and $1 \mathrm{~m}$. Salgado Coll., S. \& J. Peck leg.

Discussion. This species is easily distinguished from the others by exterior characters such as the shape of the widely separated antennal club segments, and the unique structure of the male metatrochanters, resembling those of Catops davidsoni Salgado, 1999, and some species belonging to the genera Nargus Thomson, 1867 and Choleva Latreille, 1796. The shape of the aedeagus is striking, with the strongly pointed subtriangular lobe, longer than the basal lamina but much shorter than the parameres bearing microsetae on the internal margins. The sclerotized structures of the internal sac are also very characteristic, with two lateral rows of robust imbricate teeth. The female spiculum ventrale is expanded at the apex.

Etymology. The species name refers to one of the most striking characters of this species, the long, very pointed somewhat curved male metatrochanters.

\section{Genus Falkonemadus Szymczakowski, 1961}

Falkonemadus Szymczakowski, 1961: 160.

Species type. Falkonemadus sphenisci Szymczakowski, 1961.

Falkonemadus Jeannel: Newton, 1998: 104.

Falkonemadus: Perreau, 2000: 59.

Diagnosis. Body length 2.40-2.95 mm (Fig. 39). Punctures on head and pronotum fine, sometimes scarcely discernible. Eyes small. Maxillary palps with last segment very small, cone-shaped, very narrow and much shorter than the penultimate dilated one (Fig. 40). Long, slender antennae, with weakly distinguishable club. Pronotal base with a complete ledge. Scutellum triangular, with points or slightly reticulate. Short, golden, prostrate and close pubescence. Elytra with well-defined transverse strioles and fully-developed membranous flight wings. Lacking mesosternal carina. Legs fairly robust, femurs flattened and spur of posterior tibiae shorter than first segment of tarsi. Anterior tarsi and first mesotarsal segments dilated in the male. Genital segment complete, as long as wide, basal margins more or less indented, apophysis very narrow (Figs 43 and 57).
Parameres of aedeagus lacking apical setae or with single, very small one (Figs 45 and 53). Internal sac bearing different sclerotized structures in the basal lamina region, set out in a very characteristic way in each species (Figs 44,51 and 58). Spermatheca membranous or very slightly sclerotized, in the shape of an elongated sac (Figs 48, 55 and 61).

The characters distinguishing this genus are: the unique shape of the antennae, with almost moniliform segments; the very short last segment of the maxillary palps; the narrow apophysis of the genital segment; the apex of the parameres with or without $1 \mathrm{seta}$; the internal sac with strongly sclerotized structures in the basal lamina region; the long, narrow spiculum ventrale, lacking distinct sagitta, and the spermatheca in the shape of a small elongated sac.

\section{KEY TO SPECIES OF THE GENUS FALKONEMADUS}

1. Lateral margins of pronotum almost rectilinear. Punctures on head and pronotum weakly discernible. Basal lamina of aedeagus longer than median lobe. Parameres not extending beyond apex of median lobe of aedeagus and external apical region ending in acuminate protruberance (Fig. 58)

F. avicularis sp. n.

- Lateral margins of pronotum rounded (Fig. 39). Punctures on head and pronotum well-defined. Basal lamina of aedeagus shorter than median lobe. Parameres surpassing apex of median lobe of aedeagus, apex rounded (Figs 44 and 51)

2. First male protarsal segment as wide as maximum width of tibiae. $8^{\text {th }}$ and $9^{\text {th }}$ antennal segments not transverse. Parameres extending well beyond apex of median lobe of aedeagus, notched on internal margin and narrow at apex. Internal sac bearing well-defined, symmetrical, sclerotized structures in basal lamina region (Fig. 44) .........F. sphenisci

- First male protarsal segment wider than maximum width of tibiae. $8^{\text {th }}$ and $9^{\text {th }}$ antennal segments transverse. Parameres just surpassing apex of median lobe of aedeagus, lack notch on internal margin and expanded at apex. Sclerotized structures of internal sac grouped together in basal lamina region, lacking definite shape (Fig. 51) ......F. similaris sp. n.

\section{Falkonemadus sphenisci Szymczakowski, 1961}

(Figs 40-41, 42-48)

Falkonemadus sphenisci Szymczakowski, 1961: 161.

Type locality. Kidney, Iles Falkland. Type: Coll. The Natural History Museum, London.

\section{Falkonemadus sphenisci: Perreau, 2000: 59.}

Redescription of male. Length: $2.40-2.70 \mathrm{~mm}$. Generally ovoid. Colour dark brown. Punctures on head fine, numerous and fairly close together. Maxillary palps with last segment reduced in size, much smaller than penultimate segment, which is dilated and slightly longer than wide (Fig. 40).

Antennae long, segments slightly robust, including club segments, 1.85 times as long as pronotum (Fig. 42); $3^{\text {rd }}-6^{\text {th }}$ segments almost identical; $7^{\text {th }}$ longer and slightly wider than $6^{\text {th }} ; 8^{\text {th }}$ and $9^{\text {th }}$ segments almost transverse, $10^{\text {th }}$ transverse; using the length of the $9^{\text {th }}$ segment as a basis, relative lengths of each segment from $1^{\text {st }}$ to $11^{\text {th: }} 1.34$, $1.34,1.12,1.12,1.12,1.12,1.25,0.85,1.00,1.00,1.38$; 


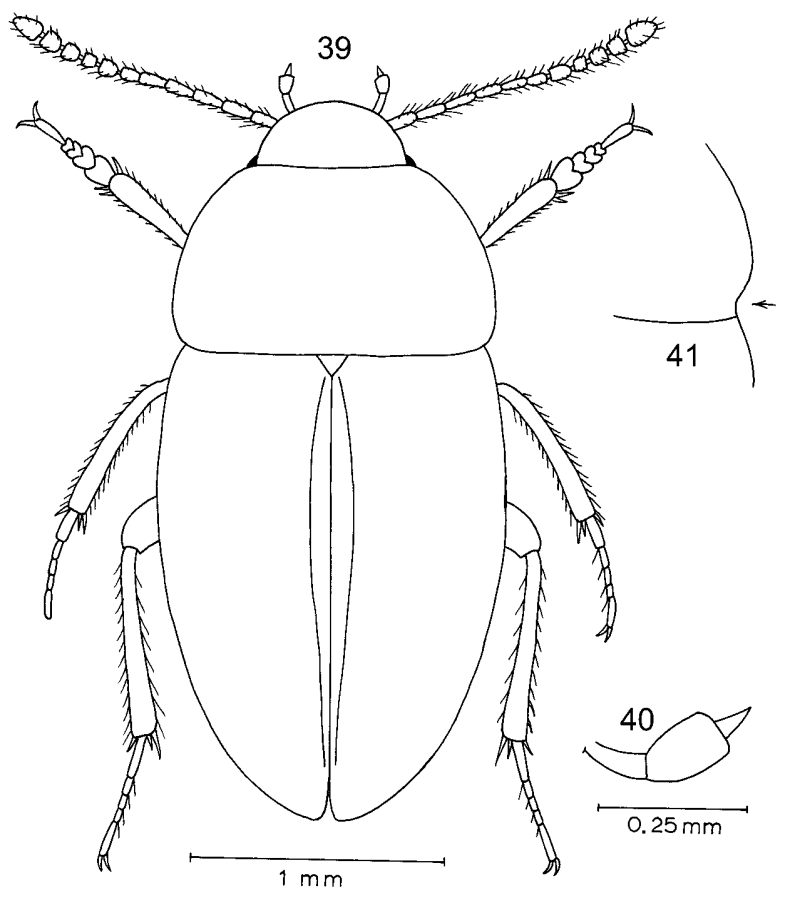

Fig. 39. Habitus of Falkonemadus similaris sp. n,

Figs 40-41. Falkonemadus sphenisci. 40 - right maxillary palp; 41 - right side of pronotum.

ratios of length to width for each segment: $2.00,2.00$, $1.75,1.67,1.67,1.58,1.50,1.08,1.05,1.00,1.50$.

Pronotum 1.65 times as wide as long, narrower than elytra, rounded towards middle and narrow posteriorly, slightly notched in some specimens (Fig. 41); basal region wider than anteriorly. Numerous, shallow punctures. Elytra elongate, weakly convex, 1.63 times as long as wide and 3.10 times as long as the length of pronotum. Strioles transverse and well-defined, scattered and a little oblique. Protarsi dilated, with first segment as wide as maximum width of tibia (1.00). Intermediate tarsi with first segment slightly dilated. Genital segment complete, as wide as long, somewhat narrow basally, very long, narrow sternal apophysis (Fig. 43).

Aedeagus with elongate, triangular median lobe, apex slightly dilated in lateral view (Fig. 44). Basal lamina shorter than median lobe, with almost straight apical margin. Ventral lamina of tegmen short. Parameres easily surpassing apex of median lobe, with large notch on internal margin of apex, where it becomes narrower; on the external margin of the apex of some specimens a pore can be seen and occasionally, a tiny seta (Fig. 45). Internal sac bearing symmetrical sclerotized structures with a unique design in the basal lamina area; towards the middle of the median lobe two fairly large symmetrical areas of numerous, small spines.

Diagnosis of female. The female has the same external morphology as the male, except for the protarsi and first segment of the mesotarsi, which are not dilated.

The most striking characters are: the very narrow sternite of VII abdominal segment, arch on posterior margin facing inwards (Fig. 46), sternite of VIII abdominal segment with long, narrow spiculum ventrale, lacking sagitta (Fig. 47). Spermatheca membranous, shaped like an elongated sac, expanded basally and narrow apically; there is also a long narrow spermathecal duct (Fig. 48).

Remarks. This species is easily identified. The main distinguishing characters are in the genitalia, particularly the shape of the parameres and the armature of the internal sac. It should be pointed out that $F$. sphenisci has fully-developed membranous flight wings, as Szymczakowski (1961) states that it is apterous. Another outstanding character is the varying shape of the basal margins of the pronotum in both sexes, which can be narrow or wide; similarly, a more or less marked narrowing can be seen in the basal margins of the genital segment; finally, the pronotal punctures varies in intensity.

\section{Material examined}

Chile. Cautín province: Bellavista, 15-30-XII-1982, 1f., A. Newton \& M. Thayer leg.; Cautín, Flor del Lago, 19-XII-1984/10-II-1985, 2m.-4f., S. \& J. Peck leg.; Cautín, Lago Caburga, 15-XII-1984/10-II-1985, 1m., S. \& J. Peck leg.; Parque Nacional Cerro Nielol, Temuco, 13-XII-1984/12-II-1985, 1m., S. \& J. Peck leg.; Parque Nacional Villarrica, Volcán Villarrica, 15-XII-1984/10-II-1985, 1m., S. \& J. Peck leg. Chiloé province: Chiloé I., Ahoni Alto, IV-1988, 1m., L. Masner leg. Llanquihue province: Parque Nacional V. Pérez Rosales, Salto Petrohue, 23-XII-1984/9-XII-1985, 1m., S. \& J. Peck leg.; Lago Chapo, 16-27-XII-1982, 2f., A. Newton \& M. Thayer leg.; 24-XII-1984/2-II-1985, 2m.-4f., S. \& J. Peck leg. Malleco province: Angol, 8-XII-1984/16-II-1985, 1m., S. \& J. Peck leg.; Victoria, 26-31-XII-1976, 7m.-1f., S. \& J. Peck leg.; Malalcahuello, 13-31-XII-1982, 2m.-2f., A. Newton \& M. Thayer leg.; Villa Portales, 22-25-XII-1976, 1m.-1f., S. \& J. Peck leg. Palena province: Chaitén, 28-XII-1984/3-I-1985, $1 \mathrm{~m} .$, S. \& J. Peck leg. Talca province: Alto Vilches, 10-13-XII1976, 1f., S. \& J. Peck leg. Valdivia province: La Unión, 17XII-1984/7-II-1985, 2m.-3f., S. \& J. Peck leg.

\section{Falkonemadus similaris sp. $\mathbf{n}$.}

(Figs 39, 49-55)

Holotype (male), description. Body length: $2.9 \mathrm{~mm}$ (paratypes: 2.70-2.95 mm). Body ovoid, somewhat convex (Fig. 39). Colour light brown. Punctures on head shallow and numerous. Maxillary palps with last segment very reduced in size, much smaller than the penultimate one, which is dilated, slightly longer than wide.

All segments of antennae weakly robust (Fig. 49), 1.80 times as long as pronotum; $3^{\text {rd }}$ to $5^{\text {th }}$ segments identical, $4^{\text {th }}$ slightly narrower; $8^{\text {th }}, 9^{\text {th }}$ and $10^{\text {th }}$ segments somewhat transverse; using the length of the $9^{\text {th }}$ segment as a basis, relative lengths of each segment from $1^{\text {st }}$ to $11^{\text {th }}$ : 1.43 , $1.43,1.20,1.20,1.20,1.20,1.38,0.82,1.00,1.00,1.55$; ratios of length to width for each segment: $2.00,2.15$, $1.67,1.74,1.67,1.67,1.45,0.94,0.97,0.93,1.45$.

Pronotum fairly small, 1.55 times as wide as long, maximum width towards middle, with sides uniformly rounded and posterior angles blunt. Punctures of pronotum fine, but stronger than those on head. Sides of elytra uniformly arched, wider than pronotum, strioles strong and separated; 1.45 times as long as wide and 3.00 times as long as the length of pronotum. Protarsi dilated, 

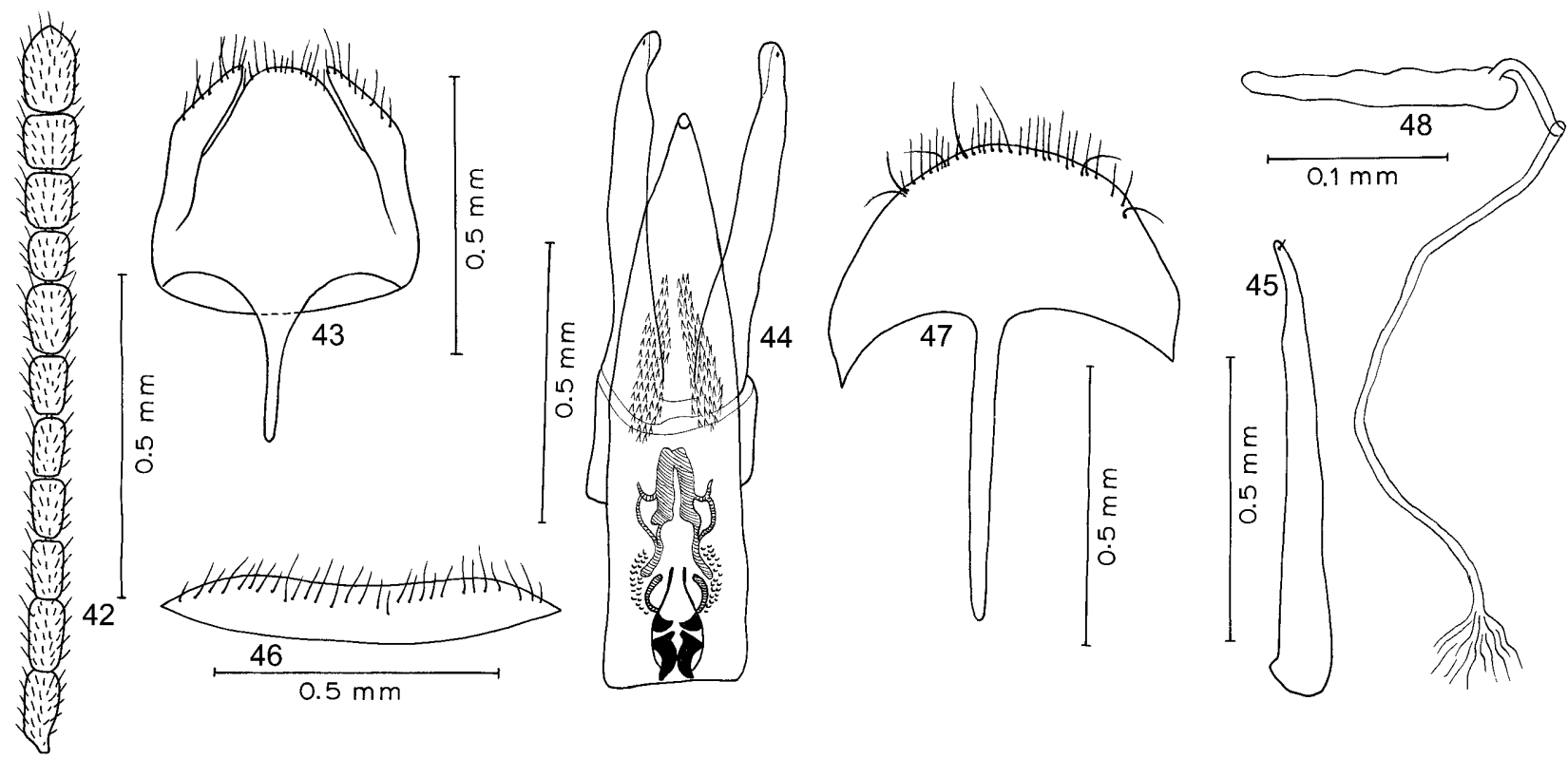

Figs 42-48. Falkonemadus sphenisci. 42 - antenna; 43 - genital segment, ventral view; 44 - aedeagus, ventral view; 45 - left paramere; 46 - VII abdominal segment; 47 - spiculum ventrale, ventral view; 48 - spermatheca and spermathecal duct, lateral view.

with first segment wider than maximum width of tibia (1.30). Intermediate tarsi with first segment weakly expanded. Genital segment as wide as long, with slight indentation in basal margins; sternal apophysis long and narrow (Fig. 50).

Aedeagus with triangular median lobe (Fig. 51), tip of apex blunt and curved in lateral view (Fig. 52). Basal lamina shorter than median lobe, with slightly curved posterior margin. Parameres only just extending beyond apex of median lobe, wide towards apex where there is no pore or seta (Fig. 53). Internal sac in basal region of lamina with a group of sclerotized structures set close together and lacking definite shape, two symmetrical arch shapes in mid region of median lobe, bearing numerous spines.

Diagnosis of female. The shape of the body is similar to the male, except for the protarsi and first segment of mesotarsi, which are not dilated.

The shape of the sternite of the VII abdominal segment closely resembles that in $F$. sphenisci. The sternite of the VIII abdominal segment has a very long, narrow spiculum ventrale (Fig. 54). The spermatheca is membranous and quite uniform in width (Fig. 55).

Type material

HOLOTYPE, male, Chile. Malleco province: $20 \mathrm{~km}$ E Manzanar, 1100 m, 19-25-XII-1976, carrion trap, S. \& J. Peck leg., FMNH Coll.

PARATYPES. Chile. Cautín province: Volcán Villarrica, $1120 \mathrm{~m}$, site 654, 15-29-XII-1982, Nothofagus dombeyi and Saxegothaea with Drimys, 1m. FMNH Coll., A. Newton \& M. Thayer leg. Chile. Chiloé province: Chiloé I., Ahoni Alto, 70 m, primary forest, III-1987, 1m. FMNH Coll., L. E. Peña leg. Malleco province: $20 \mathrm{~km}$ E Manzanar, $1100 \mathrm{~m}, 19-25-\mathrm{XII}-$ 1976, carrion trap, 2f. FMNH \& MNNC Coll., S. \& J. Peck leg.; $4 \mathrm{~km} \mathrm{~W}$ Victoria, $300 \mathrm{~m}, 26-31-X I I-1976$, carrion trap, 1f. FMNH Coll., S. \& J. Peck leg.; 12 km E Malalcahuello, 1350 m, site 650, 13-31-XII-1982, Nothofagus dombeyi and Araucaria forest, 1f. FMNH Coll., A. Newton \& M. Thayer leg.; Parque Nacional Nahuelbuta, $40 \mathrm{~km}$ W Angol, $1500 \mathrm{~m}$, 9-XII1984/17-II-1985, Nothofagus and Araucaria forest, 1f. FMNH Coll., S. \& J. Peck leg. Nuble province: Las Trancas, $70 \mathrm{~km} \mathrm{E}$ Chillán, 1400 m, 13-17-XII-1976, carrion trap, 1m.-1f. FMNH Coll., S. \& J. Peck leg.

Discussion. The morphology of this species is similar to that of $F$. sphenisci. The external characters show very little difference, nevertheless $F$. similaris sp. n. is somewhat bigger, the club segments more transverse, the male protarsi slightly more dilated and the apophysis of the genital segment shorter and broader. Also, no $F$. similaris sp. n. specimens show narrowing in the basal region of the pronotum. There is however, a marked narrowing in the basal area of the genital segment. The most outstanding differences are in the aedeagus, especially in the blunt apex of the median lobe, the parameres, which extend slightly beyond the apex of the median lobe and widen towards the apex, and the sclerotized structures of the internal sac have a completely different shape.

Etymology. The species name refers to its great similarity to F. sphenisci.

\section{Falkonemadus avicularis sp. $n$.}

(Figs 56-61)

Holotype (male), description. Length: $2.85 \mathrm{~mm}$ (paratypes: $2.70-2.90 \mathrm{~mm}$ ). Body elongated, oval. Colour brown. Punctures on head, dense, weakly discernible, slightly coarse and varying in size. Last segment of maxillary palps reduced in size, much smaller than the penultimate one, which is feebly dilated and clearly longer than wide.

Antennae long, 1.92 times as long as pronotum (Fig. $56) ; 4^{\text {th }}, 5^{\text {th }}, 6^{\text {th }}$ and $8^{\text {th }}, 9^{\text {th }}$ and $10^{\text {th }}$ segments, respectively, of equal length; $6^{\text {th }}$ and $8^{\text {th }}$ segments slightly transverse; 

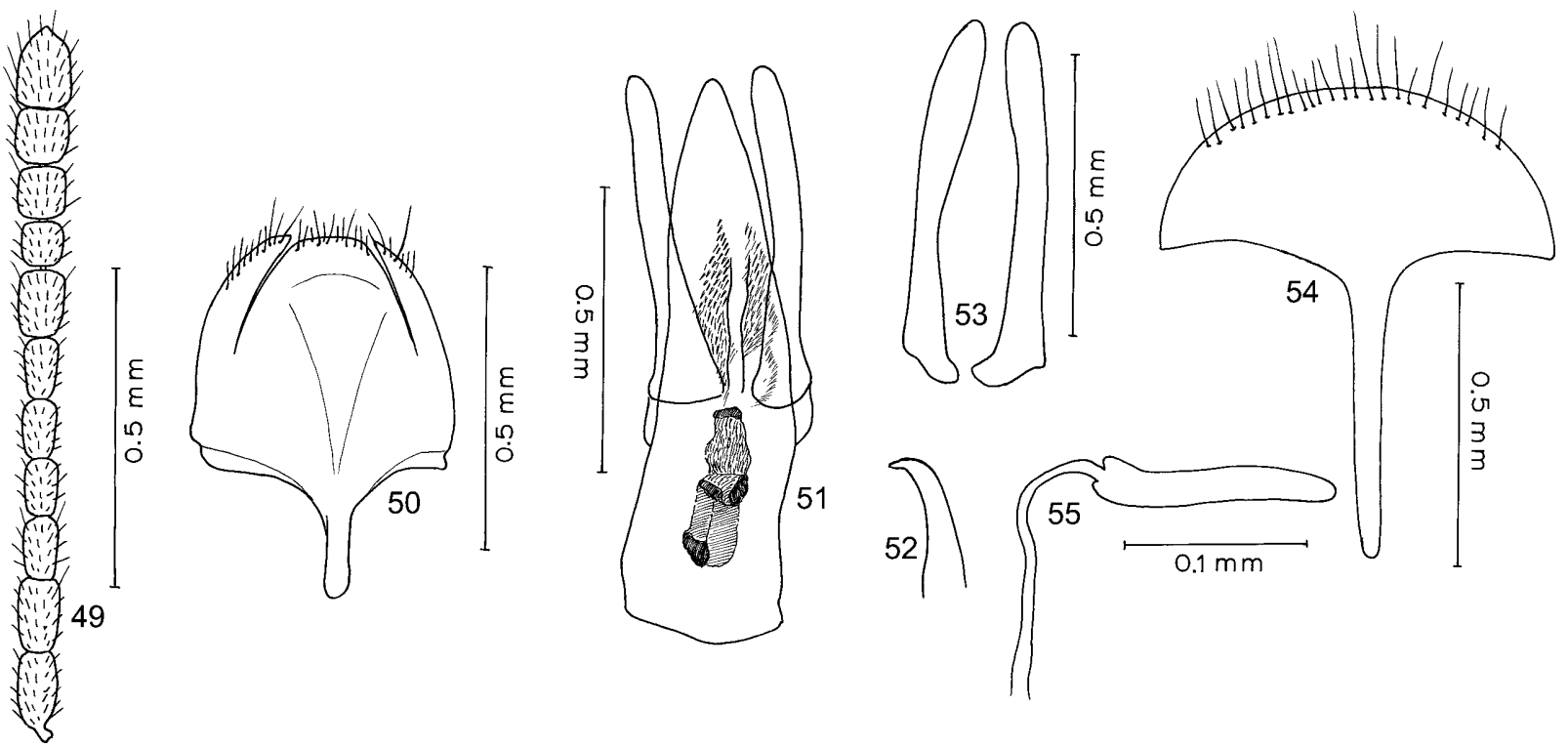

Figs 49-55. Falkonemadus similaris sp. n. 49 - antenna; 50 - genital segment, ventral view; 51 - aedeagus, ventral view; 52 apex medial lobe, lateral view; 53 - parameres, ventral view; 54 - spiculum ventrale, ventral view; 55 - spermatheca, lateral view.

using the length of the $9^{\text {th }}$ segment as a basis, relative lengths of each segment from $1^{\text {st }}$ to $11^{\text {th }}: 1.15,1.10,0.86$, $0.68,0.68,0.68,1.05,0.68,1.00,1.00,1.46$; ratios of lengths to width for each segment: $2.10,2.04,1.40,1.07$, $1.07,0.92,1.22,0.92,1.12,1.08,1.56$.

Pronotum small, 1.48 times as wide as long, more narrow than elytra, weakly rounded sides, almost rectilinear in posterior third, posterior angles very obtuse. Punctures somewhat granulate, shallow and dense. Elytra elongate, weakly convex with uniformly arched sides, 1.68 times as long as wide and 3.55 times as long as the length of pronotum; striolae transverse, strong, scattered and slightly oblique. Protarsi dilated, with first segment slightly wider than maximum width of tibiae (1.10). Intermediate tarsomeres with first segment clearly dilated. Genital segment as long as wide, with short, narrow apophysis and latero-basal margins clearly notched. (Fig. 57).

Aedeagus with apex of median lobe very rounded (Fig. 58). Basal lamina longer than median lobe, with ventral margin of apex almost straight. Ventral lamina of tegmen almost as long as basal lamina, weakly defined and scarcely protruding. Parameres robust, not surpassing apex of median lobe, bearing a unique shape resembling a bird's head at apex, and a single very short seta on external margin. Internal sac with well-sclerotized, paired symmetrical structures on laminar base, a small elongate group of spines on median lobe.

Diagnosis of female. The external morphology of the female is the same as that of the male, including body shape, antennae and punctures on head and pronotum, protarsi and first segment of mesotarsi not dilated.

Outstanding characters include: a wide arch on the posterior margin of the VII sternite of the abdominal segment, with a slight lobe in the middle (Fig. 59); the VIII sternite of the abdominal segment has a very long spiculum ventrale, without a differentiated sagitta (Fig. 60). The spermatheca is an elongate sac shape, with slightly sclerotized walls, wider at the base and narrower
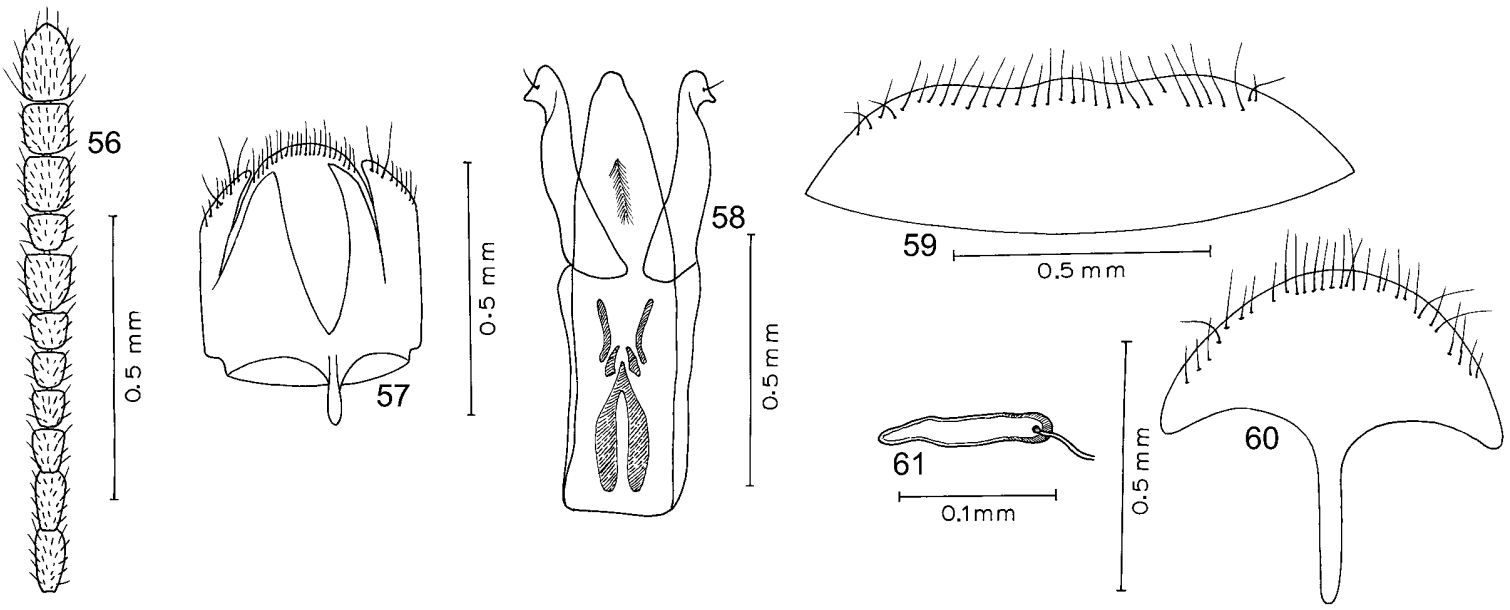

Figs 56-61. Falkonemadus avicularis sp. n. 56 - antenna; 57 - genital segment, ventral view; 58 - aedeagus, ventral view; 59 VII abdominal segment; 60 - spiculum ventrale, ventral view; 61 - spermatheca, lateral view. 
at the apex (Fig. 61). It is very likely that this structure is associated with a large spermatic gland, which is very difficult to distinguish.

\section{Type material}

HOLOTYPE, male, Chile. Osorno province: Parque Nacional Puyehue, Antillanca road, $720 \mathrm{~m}$, site 660, 18-24-XII1982, Nothofagus spp. forest, A. Newton \& M. Thayer leg., FMNH Coll.

PARATYPES. Chile. Cautín province: Volcán Villarrica, $1120 \mathrm{~m}$, site 654, 15-29-XII-1982, Nothofagus dombeyi and Saxegothaea with Drimys, 1f. FMNH Coll., A. Newton \& M. Thayer leg. Osorno province: Parque Nacional Puyehue, Antillanca road, $720 \mathrm{~m}$, site $660,18-24-X I I-1982$, Nothofagus spp forest, 1f. FMNH Coll., A. Newton \& M. Thayer leg.; P. N Puyehue, Antillanca road, $690 \mathrm{~m}$, site 661, 18-24-XII-1982, Valdivian rainforest, 1f. FMNH Coll., A. Newton \& M. Thayer leg.; $7.7 \mathrm{~km}$ NE Termas de Puyehue, 200m, site 664, 19-25-XII1982, Valdivian rainforest, 2m. FMNH \& MNNC Coll., A. Newton \& M. Thayer leg.

Discussion. Falkonemadus avicularis sp. n. is easily differentiated from $F$. sphenisci and $F$. similaris $\mathrm{sp}$. n., by the less rounded shape of the pronotum, the shorter apophysis of the genital segment and in particular the unique structure of the apices of the parameres and the sclerotized shapes in the internal sac. These structures make this species unmistakable.

Other characters such as the weakly defined punctures on the head and pronotum, the basal lamina, which is longer than the median lobe, the very long lamina of the tegmen and the slightly sclerotized spermathecal walls, markedly differentiate this species from the others.

Finally, external morphological characters, including the general shape of the body, pronotum and antennae of $F$. avicularis $\mathrm{sp}$. $\mathbf{n}$. resemble certain species belonging to the genus Nemadiolus, especially $N$. oblongus. On the other hand, the internal sac of the aedeagus, the shape of the spermatheca and fully-developed spiculum ventrale, with no sagitta make it impossible to place this species in the genus Nemadiolus.

Etymology. The species name refers to the shape of the apex of the parameres, which in outline is reminiscent of a bird's head.

ACKNOWLEDGEMENTS. I am most grateful to A.F. Newton, Associate Curator of the Field Museum of Natural History, Chicago, Illinois, for reviewing the manuscript and pointing out the necessary changes, and to both A.F. Newton and P.P. Parrillo, Division of Insects (FMNH), for allowing me access to interesting entomological material. I would like to thank the National Museum of Natural History (Paris), Mme. N. Berti; the Hungarian Natural History Museum (Budapest), O. Merkl, and the Natural History Museum (London), M. Brendell, for lending me the material, which was of great help in carrying out the comparative studies.

\section{REFERENCES}

Fairmaire L. \& Germain P. 1859: Révision des Coléoptères du Chili. Famille Silphoidae. Rev. Mag. Zool., (2 sér.) 11: 350-356.

Jeannel R. 1936: Monographie des Catopidae. Mém. Mus. Nat. Hist. Nat. (N.S.) 1: 1-433.

Jeannel R. 1957: Sur quelques Catopidés, Liodidés et Camiaridés du Chili (Coleoptera). Rev. Chil. Entomol. 5: 41-65.

JEANNEL R. 1962: Les Silphidae, Liodidae, Camiaridae et Catopidae de la Paleantarctide occidentale. In: Delamare C. \& Rapoport E. (eds): Biologie de l'Amérique Australe, Volume 1. Paris, Editions du CNRS, pp. 481-525.

Newton A.F. 1998: Phylogenetic problems, current classification and generic catalogue of world Leiodidae (including Cholevinae). In: Giachino P.M. \& Peck S.B. (eds): Phylogeny and Evolution of Subterranean and Endogean Cholevidae (= Leiodidae Cholevinae). Proceedings of a Symposium XX International Congress of Entomology. Firenze, 1996. Atti Mus. Reg. Sci. Nat., Torino: pp. 41-178.

Newton A.F. \& Peck S.B. 1975: Baited pitfall traps for beetles. Coleopt. Bull. 29: 45-46.

Perreau M. 1989: De la phylogénie del Cholevidae et des familles apparentées. Arch. Sci. (Genève) 39: 579-590.

Perreau M. 2000: Catalogue des Coléoptères Leiodidae Cholevinae et Platypsyllinae. Mém. Soc. Entomol. Fr. 4: 1-460.

Portevin G. 1914: Silphides et Liodides nouveaux. Ann. Soc. Entomol. Belg. 58: 190-198.

Salgado J.M. 1991: Nuevos datos sobre Cholevidae y Camiaridae (Coleoptera) de Chile. Elytron 5: 169-179.

SAlgado J.M. 2000: Revision of the genus Nemadiolus Jeannel, 1935 (Coleoptera: Leiodidae: Cholevinae). Elytron 14: 159-174.

SZYMCZAKOWsKi W. 1961: Espèces néotropicales nouvelles ou peu connues de la famille Catopidae (Coleoptera). Polskie Pismo Entomol. 31: 139-163.

SzYMCZAKOWSKI W. 1962: Un nouveau Nemadiopsis Jeannel de Chili (Coleoptera, Catopidae). Polskie Pismo Entomol. 32: 123-126.

SzYMCZAKowski W. 1965: The Zoological results of Gy. Topál' Collectings in South Argentina 16. Catopidae and Colonidae (Coleoptera). Ann. Hist. Nat. Mus. Nat. Hung. (Pars Zoologica) 57: 245-252.

SzYMCZAKowski W. 1968: Sur quelques Catopidae (Coleoptera) de la région néotropicale. Acta Zool. Cracov. 13: 13-27.

SZYMCZAKOWSKI W. 1971: Un genre nouveau et quelques espèces nouvelles ou mal connues des Nemadini (Coleoptera: Catopidae). Acta Zool. Cracov. 16: 397-412.

SzymczakowsKr W. 1976: Silphidae, Leiodidae, Catopidae et Colonidae (Coleoptera) du Parc National du Nahuel Huapi en Argentine. Polskie Pismo Entomol. 46: 423-438.

Received October 29, 2001; revised March 7, 2002, accepted April 24, 2002 